\title{
The Problem of Trademark Dilution and the Antidilution Statutes
}

\author{
Walter J. Derenberg*
}

One of the avowed purposes of the Lanham Trademark Act of $1946^{1}$ is stated to be "to protect registered marks used in . . . commerce from interference by State, or territorial legislation ...." The reason behind this statement of legislative intent was, of course, the realization that the protection of trademarks should be considered a matter of national concern and be so effectively regulated by federal statute under the "commerce clause" of the Constitution ${ }^{3}$ that statutory registration and protection within each of the 48 States would becoine relegated to a rather minor and subordinated role. With that objective in mind, the Senate Report on the Lanham Act states: ${ }^{4}$

The theory once prevailed that protection of trade-marks was entirely a State matter and that the right to a mark was a common-law right. This theory was the basis of previous national trade-mark statutes. Many years ago the Supreme Court held and has recently repeated that there is no Federal common law. It is obvious that the States can change the common law with respect to trade-marks and many of them have, with the possible result that there may be as many different varieties of common law as there are States. A man's rights in his trade-mark in one State may differ widely from the rights which he enjoys in another.

However, trade is no longer local, but is national. Marks used in interstate commerce are properly the subject of Federal regulation. It would seem as if national legislation along national lines securing to the owners of trade-inarks in interstate commerce definite rights should be enacted and should be enacted now.

It is not surprising, then, that since the enactment of the Act of 1946, few, if any, attempts have been made by the various states to seek compulsory state registration of locally used trademarks and that practically all state legislation since that time has centered around the enactment of the socalled "Uniform" or "Model State Registration Statute," which does not include mandatory features and expressly reserves a trademark owner's common law rights in the respective state, regardless of local registration.

* Professor of Law, New York University Law School.

160 STAT. 427 (1946), 15 U.S.C. $\$ \$ 1051-127$ (1952).

260 STAT. 444 (1946), 15 U.S.C. \$1127 (1952).

3 U.S. Covsr. art. I, $\S 8$.

4 S. REP. No. 1333, 79th Cong., 2d Sess. 5 (1946).

- The Model State Trademark Act, approved by the National Association of Secretaries of State and the Drafting Committee of the Council of State Governments, is sponsored by The United States Trademark Association. 
The theory now prevails that state registration statutes, as thus limited, may have a beneficial supplementary effect on the rights of owners of nationally used trademarks, but that any attempt by state legislation to provide for compulsory state registration might constitute an interference with interstate commerce and with the declared policy of the Lanham Act. ${ }^{8}$

What is rather noteworthy, however, is the realization, which has become more apparent as the Lanham Act comes of age, that in certain phases of rather fundamental importance to trademark owners, the act, as finally enacted, is quite deficient and lacking in scope of protection. When the more important gaps presently found in the act are closely scrutinized, it will soon be discovered that all of them had been covered in earlier versions of the act but were subsequently eliminated for fear that too effective federal sanctions against trademark infringement and unfair competition might have resulted in the misuse of trademark rights for purposes of restraint of trade.

This paper will discuss five areas of major importance on which the Lanham Act, as finally enacted, is silent, although all five have been much discussed both before the enactment of the act and since that time. The five major problems hereinafter examined have been selected because it now appears-a curious twist in the legislative history of trademark protection-that, despite the broader national scope of the Lanham Act and despite its provisions for "mcontestability" of registered trademarks and other new benefits, we must turn to state legislation and, indeed, may have to encourage more state legislation in this field, for the purpose of finding remedies in the areas in which the Federal Act of 1946 is wanting or, at least, ambiguous. These five areas are:

1. Criminal sanctions in cases of willful trademark infringement and certain forms of unfair competition.

${ }^{6}$ The act has thus far been enacted, with mimor variations, in fifteen states: ARr. STAr. ANo. tit. 70, c. 5 (1947); Ga. Laws 1952, at 134; Ill. Laws 1955, at 1646; Ind. Acts 1955, c. 174; Kan. Gen. Stat. c. 81 (Supp. 1953); Md. Code Anv. c. 63, §§ 87a-87n (Supp. 1954); Mich. Laws Reg. \& 1st Extra Sess. 1955, at 448; Miss. Code ANv. §§ 4227-01 to -15 (Supp. 1952);

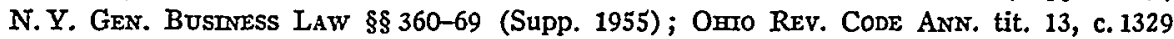
(Supp. 1956); PA. Stat. ANn. tit. 73, §11-130 (1953); S.C. Code ANN. tit. 66, c. 4, § 201 (1954); S.D. Sess. Laws 1955, at 336; Utah Laws 1955, at 297; WASH. REv. CoDE tit. 19, c. 19.76. Two states have enacted the model act with substantial changes: La. Acts 1954, at 502; Colo. Rev. Stat. AnN. c. 141, art. 1, §§1-13.

With regard to the general problem of state versus federal registration see Derenberg, The Limited Legal Effects of State Registration, 31 TRADE-MARK BULL. 267 (1936); Diggins, Federal and State Regulation of Trade Marks, 14 Law \& Contemrp. Proв. 200 (1949); Liddy, Has Congress the Constitutional Power to Legislate on the Substantive Law of Trade-Marks?, 6 Fordeam L. Rev. 408 (1937); Perry, State Trade-Mark Legislation, 37 Trade-Mark Rep. 283 (1947); Pollack, State Trade-Marks and Marks of Owership, 14 O\#то ST. L.J. 381 (1953) ; Schechter, Fog and Fiction in Trademark Protection, 36 Coxum. L. Rev. 60 (1936). For an early study of the basic constitutional problem see Barber, The Constitution and Trade-Marks, 8 U.S.T.M.A. BuLx. No. 4 (1912). 
2. "Dilution" of well known trademarks through use on totally unrelated products or services.

3. "Dilution" or "death" of a trademark as the result of "loss of the distinctive quality" thereof.

4. "Dilution" of trademarks through unauthorized use on repaired or otherwise altered products.

5. Other forms of "injury to business reputation" through misuse of trademarks, such as comparative advertising or collateral references ("a substitute for," "equivalent of," and the like).

While the Lanhain Act im its final version has remained silent on these five questions, at least four states liave stepped into the gap and enacted socalled "Antidilution" statutes which are sufficiently broad in scope to include possibilities of relief in the last four of these five categories.? There are minor variations in the language of these four antidilution statutes, but all provide for a private remedy in cases of "likelihood of injury to business reputation or of dilution of the distinctive quality of a trade name or trademark," and injunctive relief shall be available, both in case of trademark infringement or unfair competition, "notwithstanding the absence of competition between the parties or [the absence] of confusion as to the source of goods or services." 8

It is true, of course, that the antidilution statutes do not deal with the first of the previously mentioned gaps in the Lanham Act, that is, the lack of criminal sanctions; but it is a known fact that the vast majority of the 48 States many decades ago incorporated criminal sanctions not only in their registration statutes but in numerous other special criminal statutes as well which have become known as so-called "refillable container" stat-

7 The following states have enacted the "Antidilution" statute: Ga. Sess. Laws 1955, at 453 ; Ilr. Rev. Stat. c. 140, § 4a (1953) ; Mass. IAws ANN. c. 110, § 7A (1954); N.Y. GeN. Bus. LAw §368-c(3). The New York Act is identical with the Massachusetts act and reads as follows:

"Likelihood of injury to business reputation or of dilution of the distinctive quality of $\mathbf{a}$ trade name or trade-mark shall be a ground for injunctive relief in cases of trade-mark infringement or unfair competition, notwitlstanding the absence of competition between the parties or the absence of confusion as to the source of goods or services."

The Illinois act and the most recent Georgia act are identical. The Georgia act adds section 17a to the Trade-Mark Act of 1952, and reads as follows:

"Every person, association, or union of working inen adopting and using a trade-mark, trade name, label or form of advertisement may proceed by suit, and all courts having jurisdiction thereof shall grant injunctions, to enjoin subsequent use by another of the same or any similar trade-mark, trade name, label or form of advertisement if there exists a likelihood of injury to business reputation or of dilution of the distinctive quality of the trade-mark, trade name, label, or form of advertisement of the prior user, notwithstanding the absence of competition between the parties or of confusion as to the source of goods or services; except that the provisions of this section shall not deprive any party of any vested lawful rights acquired prior to the effective date of this amendatory Act."

8 See statutes cited at note 6 supra. 
utes and which outlaw unauthorized use of trademarks or obliteration or defacing thereof. We shall, therefore, commence with a brief discussion of criminal infringement, because-while not included in the state antidilution laws-the lack of federal criminal sanctions has undoubtedly become one of the main reasons why state legislation and protection have assumed a considerably more important role in trademark protection than the sponsors of the Lanham Act of 1946 had anticipated. ${ }^{\circ}$

\section{THE "CRIME" OF TRADEMARK INFRINGEMENT}

It is indeed astomishing that the United States has remained perhaps the only major nation which in its national law fails to provide for criminal sanctions even in the case of willful trademark infringement. This becomes even more disconcerting if it be considered that in other branches of industrial and literary property law, our federal statutes do include provisions of this sort. The Copyright Act, section $28,{ }^{10}$ makes willful infringement for profit of any copyright secured under the act of 1909 a misdemeanor and any person who knowingly or willingly abets such infringement is equally hable. ${ }^{11}$ Are we to conclude that the valuable property symbolized by a trademark was deemed by our Legislature not to be entitled to the same degree of protection against theft and piracy which patents, copyright and other intangible business assets have traditionally enjoyed?

The legislative history on this point is both peculiar and revealing. It will be recalled that our first Federal Registration Act of $1870^{12}$ and the criminal statute which was based thereon in $1876^{13}$ were declared unconstitutional by the United States Supreme Court in the famous Trade-Mark

${ }^{9} \mathrm{~A}$ somewhat similar development, although on a smaller scale, seems to have become noticeable in the antitrust field. In a recent address by the Attorney General of the State of New York, Jacob K. Javits, on "The Role of State Antitrust Laws," in January 1956, the appointment was announced of a distinguisbed committee for the purpose of investigating the present scope and effect of the New York State Antitrust Legislation. This step was taken because a necessity was found to exist in New York "to supplement the federal antitrust program by adequate action at the state level." The existence of local restraints was said to pose a major problem calling for the application of adequate remedial measures within the state. Cf. ATr'y

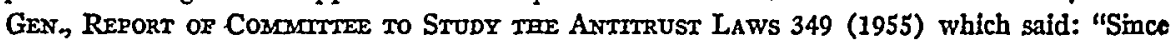
State antitrust laws, with [a] few exceptions, have not been fully developed or enforced, national antitrust policy must make adequate provision for dealing with all inarket restraints within its ambit."

1035 STAT. 1075 (1909), 17 U.S.C. § 104 (1952).

11 See Howers, The Copyright Law 166 (3d ed. 1952).

1216 Srat. 198 (1870), entitled "An act to revise, consolidate, and amend the Statutes relating to Patents and Copyrights." The part of this act relating to trademarks is embodied in chapter 2, title 60 , sections 4937 to 4947 , of the Revised Statutes.

1819 STaT. 141 (1876), "An act to punish the counterfeiting of trade-mark goods and the sale or dealing in of counterfeit trade-mark goods." 
Cases, ${ }^{14}$ on the ground that they had been erroneously based on the "patent and copyright clause" of the Constitution. What may not be generally known, however, are the circumstances which brought about the enactment of the first and only criminal infringement statute which this country has had to date. In 1868 the Umited States entered into its first treaty for the reciprocal protection of trademarks with a foreign nation, which in this instance was Russia. ${ }^{15}$ Under the treaty it was stipulated that counterfeiting of trademarks "shall be strictly prohibited and repressed ...." A similar treaty was entered into with Belgium during the same year. ${ }^{18} \mathrm{It}$ was thought that damages at common law for trademark infringement or the availability of a federal registration alone would not satisfy the requirement of "strict prohibition and repression" and that, therefore, criminal sanctions shonld be made available. This was the origin of the act of 1876 , entitled "An act to punish the counterfeiting of Trade-Mark Goods, and the sale or dealing in of counterfeit Trade-Mark Goods."17 In reporting this bill, the following statement was made: ${ }^{18}$

No United States statute yet exists providing penal remedies to punish the counterfeiting of trade-mark goods or the sale or dealing in the same. The evils and injuries to long-suffering commercial and manufacturing interests consequent upon this omission imperatively demand prompt relief and a speedy application of searching remedies.

When the Supreme Court held that the registration statute which underlay the criminal act of 1876 was unconstitutional, the door seemed to have been closed permanently to any determined effort to provide for eriminal sanctions against trademark infringement even within the scope of the commerce clause of the Constitution. Neither the Trade Mark Act of March 3, $1881,{ }^{19}$ nor the act of February 20, 1905, ${ }^{20}$ nor the Lanham Act of $1946^{21}$ included any criminal infringement provisions whatsoever. When

14100 U.S. 82 (1879).

15 articie Respecting Trade-Marks, additionat to the Treaty of Navigation and COANTERCE of DECEMIBER 6-18, 1932, concluded at Washington, Jan. 27, 1868, proclaimed October 15, 1868. More fully quoted in REPORT OF THE CoMcrissroners APPOINTED TO REVISE the Statutes Relateng to Patents, Trade akd Other Marks, and Trade and Comanerctal NAMIES 93, 335 (1900).

${ }^{18}$ Concluded at Brussels, Dec. 20, 1868, proclaimed July 30, 1869. Id. at 93 et seq., 326. 1719 Stax. 141 (1876).

184 Corg. Rec. 4775 (1876). Mr. Sampson of the Committee on Patents quoting frum a petition by "nearly 400 of the leading manufacturers, merchants, and dealers of New York, Boston, and Philadelphia."

1021 SxAT. 502 (1881), entitled "An act to authorize the registration of trade-marks and protect the same."

2033 SraT. 724 (1909), entitled "An Act To authorize the registration of trade-marks used in commerce with foreign nations or among the several States or with Indian tribes, and to protect the same."

21 See note 1 supra. 
an effort was made, shortly after the act of 1881 was enacted, to allege that the Criminal Act of 1876 had not been dead but "simply dormant" until the act of 1881 became effective, ${ }^{22}$ the courts held that, contrary to this view, the act of 1876 became a nullity when the underlying registration statute of 1870 was declared unconstitutional. ${ }^{23}$

Perhaps the fact that the Supreme Court's decision in the Trade-Mark Cases $^{24}$ involved a criminal indictment was the psychological reason why we have shied away, ever since that time, from providing for criminal sanctions against the infringement of registered trademarks; however, both from an historical and practical point of view, this would seem hardly an acceptable justification for such inaction. But we should recall at this time that no less a statesman than Thomas Jefferson, as Secretary of State, recommended not only the enactment of federal trademark legislation but of criminal sanctions as well. In his famous report of December 9, 1791, he said: ${ }^{25}$

[I] $t$ will, therefore, be reasonable for the General Government to provide in this behalf by law for those cases of manufacture generally, and those only which relate to commerce with foreign nations, and among the several States, and within the Indian Tribes.

And that this may be done by permitting the owner of every manufactory to enter in the records of the court of the district wherein his manufactory is the name with which he chooses to mark or designate his wares, and rendering it penal in others to put the same mark to any other wares.

In commenting upon this report, the committee, which laid the groundwork for what subsequently became the act of 1905, stated in 1900 that the essential features of the law suggested by Thomas Jefferson (including the provisions for punishment of infringers) "are today the essential features of the trademark laws of all foreign countries ... which have any pretension to commercial importance." 26

In the first American treatise on the law of trademarks, published in $1860,{ }^{27}$ the author observed that the civil remedies, whether at law or in equity, afforded but little protection to the public ${ }^{28}$

22 Browne, Trade-Marks $\$ 371$ (2d ed. 1885).

23 It was so held in U.S. v. Koch, 40 Fed. 250-52 (C.C.E.D. Mo. 1889). For detailed discussion of this case see Hopkns, Trade-Marks, Tradenames and Unfatr Competition 408 (4th ed. 1924).

24100 U.S. 82 (1879).

25 RePORT OF THE COMmisstoners, etc., supra note 15, at 89, quoting Jefferson's Complete Works, Washington, 1854, vol. 7, 563 ; Ax. State Papers, vol. 14, p. 48. Report of Mr. Jefferson, dated Dec. 9, 1791, on the petition of Samuel Breck and others of Boston, asking that they be given exclusive right to use certain marks for designating sailcoth of their manufacture. (Emphasis added.)

26 REPORT OF THE COMMISSIONERS, etc., supra note 15, at 89.

27 Upton, a Treatise on the Law of Trade Marks with a Digest aNd Review of thi ENGIISH AND AMERTCAN AUTHORITIES (1860).

28 Id. at 247. 
against the frauds and impositions of those who dress their spurious goods in the guise and habilinents of the honest manufacturer, in order to pass thein off upon the unsuspicious customer.

The easily won profits that flow from such an appropriation of the reputation of another, present too powerful a temptation to the unscrupulous, to be overcoine by the apprehended possibility of being stripped of their disguises, and compelled to relinquish their ill-gotten gains, as the consequence of a costly itigation.

The treatise concluded with a reference to the New York State statute ${ }^{2 \theta}$ which made willful trademark infringement a misdemeanor, and observed: ${ }^{30}$

We do not remember to have seen a report of any prosecution under this or any sinilar penal statute, but, the policy of such enactments, and the necessity of their rigid enforcement, in all proper cases, cannot fail to be fully acknowledged by all who have a just appreciation of the great inportance to the public interests as well as to individual rights, of maintaining inviolate, that peculiar property which serves to designate and identify the goods, and wares, and merchandise of the artisan, the manufacturer, and the merchant, which ininister to the constant necessities of all, and which furnish the sole assurance and guaranty of their genuineness, purity and integrity.

Twenty-five years later, in the second edition of his treatise on trademarks, Browne observed:" "Penal restraint in the matter of fraudulent imitations of trade-marks originated in stern necessity." And Greeley, in his valuable comparative study published in 1899 , significantly states: ${ }^{32}$

In practically all countries which have laws providing for the registration of trademarks and in inany countries in which registration is not provided for, the wilful counterfeiting of a trademark is under the law an offense punishable by fine or inprisonment. The owner of a trademark may under such laws not only recover damages for the injury done to his business by the unlawful use of his trademark, but has the further protection of a penal statute against deliberate and wilful infringement of his rights. In many of the several states of the United States wilful infringement of a trademark is made an offense punishable by fine or imprisonment, but under the present United States law the only remedies are the common law remedies of damages and injunction.

Despite this uniform and rather strong evidence of a need for criminal sanctions, the psychological reaction from the Trade Mark Cases ${ }^{33}$ was such as to effectively nullify all efforts in that direction after that time. The question was not broached again until the hearings in 1932 on the revision of the act of 1905, when the late Frank I. Schechter, in testifying

\footnotetext{
29 N.Y. Rev. STaT. pt. IV, tit. 6, c. 1, § 49 (5th ed. 1859).

30 Uptos, supra note 27 , at 247.

31 Browne, Trade-Marks $\S 370$ (2d ed. 1885).

32 Greelex, Foreign Patent and Trade-Mark Laws $\$ 179$ (1899).

33100 U.S. 82 (1879).
} 
before a Congressional committee, suggested the inclusion of penal provisions in the new legislation. ${ }^{34}$

The early versions of the Lanham Act all included criminal provisions. ${ }^{35}$ There was some discussion of the criminal provisions during the hearings on H.R. $4744^{38}$ in March 1939, during which it was suggested that a definition of counterfeiting should be included in the bill. In 1941, the criminal section with one minor amendment was introduced again in H.R. 102, ${ }^{\text {a7 }}$ but during these hearings some opposition against inclusion of criminal provisions was raised, particularly in a statement submitted by the National Retail Dry Goods Association. ${ }^{38}$ By June 1942, when the Lanham Act appeared under S. 895 on the Union Calendar, No. $818,{ }^{39}$ the criminal provisions had been eliminated in toto and were never reincorporated in the proposed act thereafter. The elimination apparently was due primarily to opposition by the majority of the members of the Trademark Committee of the American Bar Association, which stated in its report: ${ }^{40}$

The "Criminal Offenses" section, No. 41, has been the subject of much criticism, particularly on the part of retailers and carriers who believe that they would be put to unwarranted trouble and expense if this provision is included in a trade-mark statute. The committee, therefore, decided to recommend that this section be stricken in its entirety.

Only Miss Daphne Robert, now Mrs. Daphne Leeds, Assistant Commis-

34 Hearings Before the House Committee on Patents, 72d Cong., 1st Sess., at 21 (1932). Mr. Schechter there said: "[U]nless, furthermore, Congress puts teeth into such Federal legislation by penal provisions against infringement, then what E. S. Rogers has so aptly termed 'the expensive futility of trade-mark registration' will be merely facilitated and perpetuated, not eliminated, to the enrichment of members of the legal profession as well as to the continuing aid and comfort of those commercial highwaymen who operate in security and whom Robert Louis Stevenson has thus immortalized:

The silent pirates of the shore

Eat and sleep soft, and pocket more

Then any red, robustious ranger

Who picks his farthings hot from danger."

During his testimony, the then Commissioner of Patents Robertson asked Mr. Schechter: "Has not our Congress always been rather reluctant to put any penal provision in our trademark laws?" The reply was: "My recollection is that in the very first law they passed they put such a penalty provision im. It was declared unconstitutional, because it seemed to cover interstate as well as intrastate commerce; but I do not understand there was any objection on that ground. A good many of the State statutes have made that provision."

35 H.R. 9041, 75th Cong., 3d Sess. \$35 (1938).

36 76th Cong., Ist Sess. \$ 42 (1939); Hearings Before the Subcommittee on Trade-Marks of the House Committee on Patents, 76th Cong., 1st Sess. (1939).

37 77th Cong., 1st Sess. § 41 (1941).

as Hearings Before the Subcommittee on Trade-Marks of the House Committee on Patents, 77th Cong., 1st Sess., at 188 (1941).

39 77th Cong., 2d Sess. (1942).

40 astertcan Bar Ass'n, Section of Patent Trade-Mart asd Copyrtoet Law, Reporx

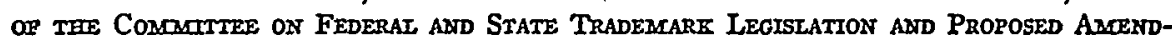
MRRNTS TO THE LANEAMS TRADE-MARE BIII 11 (1940-1941). 
sioner of Patents, appears to have voted for retention of these provisions. She said: ${ }^{41}$

I am still of the opinion that a criminal provision is not out of place in our trade-mark statutes. The proposed language of the Lanham Bill was unsatisfactory, but I believe that through rephrasing this section, it could be advantageously retaimed.

This, then, is where we stand today. Alone among all major nations of the world, we have not seen fit to make deliberate piracy and fraudulent use of well known trademarks a federal misdemeanor. We have nothing to show that compares with the effective provisions of the British Merchandise Marks Act, ${ }^{42}$ under which only recently an association of soft drink manufacturers in England effectively brought criminal proceedings against a manufacturer of a bleach who used a large number of bottles into which the trademarks of certain famous soft drink manufacturers had been indelibly stamped. ${ }^{43}$ We lave nothing whicl corresponds to the provisions of the Canadian statute whicli became effective in April 1955, ${ }^{44}$ under which any forgery of a trademark or false use of a genuine trademark is a criminal offense. Under section 353(b) of the new Canadian Criminal Code, the defacing of trademarks, the unauthorized use of trademarks on bottles, and the use of trademarks on reconditioned articles are criminal offenses, and the Code provides for many more misdemeanors of this type. ${ }^{45}$

As a result of the total lack of criminal sanctions in the Lanham Act, we are frequently forced to suggest to clients that it may be advisable for them to register their important trademarks in some key states so as to have at least one remedy available which might serve as an additional deterrent against deliberate piracy.

It could, of course, not be expected that any state legislation would be sufficiently altruistic to make a misuse of a federally registered trademark a state misdemeanor, but one state statute-probably the best of them all, in any event-has been found under whicli such a gesture has been made. That state is California. Interestingly enough, section 350 of the California Penal Code, ${ }^{46}$ in addition to many other penal provisions involving trademarks, expressly provides that the willful counterfeiting or misuse of any trademark which has been duly recorded in California or with the Commissioner of Patents in the United States Patent Office is a misdemeanor. Thus

41 Ibid.

42 Cf. Moulton and Davis, The LAw of Merchandise Marks (1954).

43 See Stevens, Containers and Trade Mark Rights, 45 Trade-Mark REP. 1257 (1955).

44 2-3 Eliz. 2, c. 51 (Canada) §§ 349-364; 88 Canada Gazette 3297 (1954).

45 The new Canadian provisions are dealt with in a comprehensive article by Harold G.

Fox, Criminal Offenses Under the Canadian Trade Marks Act, 46 TradeMarK Rer. 371 (1956).

46 Approved March 27, 1897. 
it would seem that the owner of a nationally famous trademark, which has been registered under the Lanham Act but may not have been registered in the state of California, may secure a criminal conviction in California for infringement of a trademark bearing the notice, "Reg. U.S. Pat. Off.," even though he may not be able to secure such a conviction under the federal law which forms the basis of his registration $!^{47}$

II

"DILUTION" THROUGH USE ON UNRELATED PRODUCTS

This is the dilution concept which immediately led to the enactment of the State Antidilution Statutes and will, therefore, be considered first before other forms of trademark infringement which might also fall within the broad language of those statutes will be examined. The history of the dilution concept is probably too well known by now to require any detailed restatement here. Suffice it to say that the concept originated in England when the British court protected the trademark "Kodak" against use on bicycles, ${ }^{48}$ and further developed when a lower German court held that the famous trademark "Odol" was infringed by use of the same mark for totally unrelated products, ${ }^{49}$ and cancellation of the latter registration was ordered by the court. Contrary to an earlier decision by the appellate court of Hamburg, ${ }^{50}$ in which the owners of the mark "Kodak" were held not en-

47 The majority of states which have enacted the "Model Act" have specific reservations with regard to their respective penal codes which had been previously enacted and which provide criminal sanctions. Some of these states have actually added substantive criminal provisions to the Model Act. This was recently done, for instance, in the State of Utah by S.B. No. 95 (May 1955), Utah Laws 1955, at 297.

48 Eastman Photographic Materials Co. v. John Griffith Corp., 15 R.P.C. 105 (1898).

49 Civil Court, Elberfeld, 25 JURISTISChe WOCHEMSCHRLFT 502; XXV Markenschutz UND WeTTBE WERB 264, Sept. 11, 1925. In a decision of Noveunber 1955, the Appellate Court of Dusseldorf held that the court could not recognize the concept of "potential" dilution but that protection should be granted only if and when the trademark had actually become famous, 58 GRUR 172, 176 (1956).

A rather extreme case of another form of dilution not mvolving actual "confusion" has just been reported in Time, Aug. 6, 1956. According to Time, the owner of the famous "4711" trademark for eau de cologne got an injunction in Cologne, Germany, against a manure collector who used his telephone number, 4711, painted in 20-inch high numerals across both sides of his horse-drawn fertilizer wagon. This case is reminiscent of the Patent Office proceeding in which, many years ago, an applicant who sought to register the term "Soisette" for toilet paper was opposed by the registrant of "Soiessette" as a trademark used on cotton goods. Ponemah Mills v. Universal Crepe \& Tissue Mills, Inc., 18 TrADE-MARK REP. 132 (1928). The Commissioner in dismissing the opposition pointed out that the appropriation of the mark in question by the applicant could not "cause the goods of the opposer to be brought into public ridicule, contempt and disrepute." In a subsequent infringement proceeding between the sane parties involving the same trademarks, the court came to the same conclusion, holding that there was "not the slightest association in use between the two products nor in manufacture." The argument that there was "an indelicacy" about using plaintiff's inark in connection with defendant's goods was rejected. 19 Trade-Mark ReP. 220 (1929).

50 The earlier decision is reported and discussed in 19 U.S.T.M.A. BuLL. 105 (1924). 
titled to cancel registration of the same mark for bath tubs, ${ }^{51}$ it was held in the Odol case that a famous trademark should be protected against "dilution" (the German word being Verwaesserung), and that it would lose its selhing power if others were allowed to use it as a designation even for totally different products. The Gerinan court said in the course of its decision: ${ }^{52}$

To be sure, the parties, on account of the wholly different goods put out by them are not in actual competition. That, however, is beside the point. The complainant has created a demand for its goods, while employing thereon a word having drawing power, for only through the year-long activity of the complainant was its selling power acquired .... Complainant's ability to compete with other manufacturers of mouth wash will be impaired if the significance of its mark is lessened.

It was this language and this concept which led the late Frank I. Schechter strongly to suggest that the "dilution" concept be made part of the American law of trademarks, and that the uniqueness of well known trademarks should be protected as an independent property right, regardless of the presence of confusion. ${ }^{53}$ When testifying before a Congressional committee in 1932, Schechter once inore urged recognition of the dilution concept. He said: ${ }^{54}$

I think there is not only the question of deception of the public, but I beheve from the reasoning of this German court I liave quoted, the person who has the trade-mark slould be able to prevent other people from vitiating the originality, the uniqueness of that mark. If you take Rolls Roycefor instance, if you allow Rolls Royce restaurants and Rolls Royce cafeterias, and Rolls Royce pants, and Rolls Royce candy, in 10 years you will not have the Rolls Royce mark any more. That is the point.

In the proposed new trademark act which he drafted in 1932 and which became known as the Perkins Bill, ${ }^{55}$ a provision was included not ouly to protect any registered mark which was "a coined or invented or fanciful or arbitrary mark," against marks which may be likely to cause confusion, but also against users which may "injure the good will, reputation, business, credit or securities of the owner of the previously used trademark . . ."

51 See discussion of this case in Schechter, The Rational Basis of Trademark Protection, 40 HARV. L. REv. 813, 831 (1927).

52 Quoted in Schechter, supra note 51, at 832. (Emphasis added by Schechter.)

53 "Quite apart from the destruction of the uniqueness of a mark by its use on other goods, which will be discussed later on, once a mark has come to indicate to the public a constant and uniform source of satisfaction, its owner should be allowed the broadest scope possible for 'the natural expansion of his trade' to other lines or fields of enterprise." Schechter, supra note 51 , at 823 .

54 Hearings Before the House Committee on Patents, 72d Cong., 1st Sess. 15 (1932).

55 H.R. 11592, 72d Cong., 1st Sess. (1932).

$50 I d$. at $\$ 2$ (d) (3). 
Congress, however, took no further action on the Perkins Bill and no similarly broad proposal was ever again introduced during the many years the Lanham Act was under consideration. The result has been that the Lanham Act, while abolishing the old concept of "same descriptive properties" which had been used throughout the Act of 1905, and substituting a broader test of likelihood of confusion therefor, failed to provide for the recognition of the dilution concept even in case of famous trademarks, unless some form of confusion, be it as to origin or as to sponsorship, can be established. Although there has been considerable legal writing on the subject since Schechter first suggested the adoption of this theory, ${ }^{67}$ it seems that only one distinguished American writer has spoken out clearly in favor of recognizing "dilution" as a separate tort in the form of an invasion of the trademark owner's exclusive right even in the absence of any finding of "competition" or "confusion." George Middleton has pointed out in a provocative article of recent date, that even in those relatively few cases in which our courts have resorted to the dilution concept for the purpose of granting protection against use of a famous name on completely dissimilar products, they still found it necessary to justify the granting of relief by finding some semblance of "confusion." Even in the famous Tiffany case, ${ }^{60}$ usually referred to as the landmark case on dilution in the United States, an element of confusion was present as a result of use of the "Tiffany" name on motion pictures, because of certain slogans and other displays which the defendant used in connection with the name. Some vague element of confusion is also readily discovered in the other cases in which the dilution theory was invoked. ${ }^{11} \mathrm{We}$

57 Brown, Advertising and the Public Interest: Legal Protection of Trade Symbols, 57 YArF L.J. 1165 (1948) ; Gamer, Narrow and Weak Trade-Marks, 22 GEo. WasH. L. Rev. 40 (1953); Goble, Where and What a Trade-Mark Protects, 22 Irc. L. Rev. 379 (1927); Oates, Relief in Equity Against Unfair Trade Practices of Non-Competitors, 25 IrL. L. Rev. 643 (1931); Wolff, Non-Competing Goods in Trademark Law, 37 Colux. L. Rev. 582 (1937) ; Note, 66 Harv. L. REv. 1094 (1953).

583 Catimann, Unfatr Competttion and Trade-Marks 1643 (2d ed. 1950); Callmann, Trademark Infringement and Unfair Competition, 14 LAW \& ConTEMr. ProB. 185 (1949);

Callmann, Unfair Competition Without Competition?, 95 U. PA. L. REv. 443 (1947).

59 Middleton, Some Reflections on Dilution, 42 Trade-MARK REP. 175 (1952).

60 Tiffany \& Co. v. Tiffany Productions, Inc., 264 N.Y.Supp. 459 (1932), aff'd, 237 App. Div. 801, 260 N.Y. Supp. 821 (1932), aff'd, 262 N.Y. 482, 188 N.E. 30 (1933). The lower court did refer to a number of witnesses who testified that defendant's motion pictures "marked as indicated above [with a diamond in conjunction with the name Tiffany], its programs, electric signs and lobby displays, have in fact caused confusion in their minds and led them to believe that plaintiff was connected with the production of defendant's pictures." 147 Misc. 679, 681, 264 N.Y. Supp. 459, 461 (Sup. Ct. 1932).

61 This was true, inter alia, in Triangle Publications v. Rohrlich, 167 F.2d 969 (2d Cir. 1948); Stork Restaurant v. Sahati, 166 F.2d 348 (9th Cir. 1948); Wall v. Rolls-Royce of America, 4 F.2d 333 (3d Cir. 1925) ; Bulova Watch Co. v. Stolzberg, 69 F. Supp. 543 (D. Mass. 1947) ; Alfred Dunhill of London v. Dunhill Shirt Shop, 3 F. Supp. 487 (S.D.N.Y. 1929). For a complete list and analysis of all dilution cases up to about 1943 see 148 A.L.R. 1, 75. 
may therefore have to agree with Middleton's conclusion that, at least as far as our federal law is concerned, dilution as such has not been made a statutory tort or a ground on which registration may be refused or a registered mark cancelled. We may also have to agree with him that ${ }^{62}$ "the courts generally have not regarded dilution as a common law tort in its own right, although they have occasionally used it as a makeweight in cases where confusion or its hkelihood was the ratio decidendi. So far as I know no case has turned on dilution alone." But we do not have to concur in his ultimate conclusion that the dilution concept has remained "alien to the law of trade-marks" in this country and should never be recognized in the absence of a finding of likelihood of confusion. ${ }^{63}$ Nor would we have to agree that "dilution in the last analysis is a non-statutory form of patent or copyright infringement and as such has no legal sanction." ${ }^{64}$ On the contrary, it is suggested that the use of a celebrated name or trademark even by a noncompetitor on totally unrelated goods should be considered tortious and actionable quite regardless of any far-fetched likelihood of confusion. To condemn such misappropriation would not import patent or copyright principles into our trademark law but would be nothing more than an extension of modern principles of tort law to this particular phase of business conduct. Since we must admit that our federal trademark statute falls short of giving recognition to this concept, it is doubly significant that a step in this direction was taken by the four states which have thus far enacted antidilution legislation. ${ }^{65}$

Unfortunately, all four antidilution statutes are so worded as to invite reliance thereon not only by the owners of well known or famous trademarks or names for whose protection this legislation was intended, but also by others who can make no claim to such celebrity or reputation. While no precedents relying upon or interpreting the antidilution statute have been found in Illinois or Georgia, it has already become clear from the Massa-

62 Middleton, Some Reflections on Dilution, 42 Trade-Mark REP. 175, 187 (1952).

63 Ibid.

ot Ibid.

65 It is, perhaps, particularly significant to note that the first two states in which legislation was enacted, Massachusetts and mlinois, had always been particularly conservative and unwilling to extend the doctrine of unfair competition beyond the narrow limits of "passing off." Typical of this conservative earher trend in Massachusetts was Kaufman v. Kaufman, 223 Mass. 104, 111 N.E. 691 (1916). In Ilinois, all state court decisions prior to Lady Esther v. Lady Esther Corset Shoppe, 317 Il. App. 451, 46 N.E.2d 165 (1943), had held that there could be no unfair competition without passing off. Cf. Stevens-Davis Co. v. Mather \& Co., $230 \mathrm{Ml}$. App. 45, 48 (1923) (referred to by Senator Burt in introducing Senate Bill No. 292, April 1, 1953, which became the Illinois Antidilution Statute), which stated:

"The courts in this state do not treat the 'palming off' doctrine as merely the designation of a typical class of cases of unfair competition, but they announce it as the rule of law itself-the test by which it is determined whether a given state of facts constitutes unfair competition as a matter of law." 
chusetts decisions and from at least two New York decisions that until now, no case involving protection of a famous trademark against dilution, that is, use of the name by another party on totally different products, has been reported in either of these states, but that the statutes have been invoked only in cases in which, in all probability, the same result would have been reached in the absence of such legislation.

Let us take a quick glance at recent developments in these jurisdictions.

A. Massachusetts The legislative history, meager though it may be, which led to the adoption of the first antidilution statute by Massachusetts, reveals some rather significant facts. ${ }^{66}$ In its original version, Massachusetts House Bill No. 656 of 1947 was but a short amendment to the General Laws of the State which would have prohibited a person from assuming as his business name, in whole or in part, "ar "any coined or peculiar word which constitutes or is contained in any trademark or label recorded in this commonwealth, or in the name of any domestic corporation or foreign corporation qualified to do business in this commonwealth without the consent in writing of the owner of such trademark or label or of such corporation." In a meinorandum accoinpanying House Bill No. $656,{ }^{\circ 8}$ reference was made to decisions in other states and in England which had protected such well established trademarks as "Kodak," "Philco," "Aunt Jemima," "Tiffany," and numerous others. It was pointed out that when a well-known trademark was used by others on noncompeting goods, a dilution of the mark might result and its selling power be gradually weakened. It was then emphasized that the law of Massachusetts had been hampered in this respect by old precedents which would not grant relief in the absence of likelihood of confusion or deception of purchasers even in cases involving well known trademarks. Particularly significant, in the light of subsequent developments, is the following paragraph which was included in the special memorandum to the legislature: ${ }^{80}$

No monopolies can be created by this amendment, and none are souglt. It applies only to "newly assumed" uses, and lias no retroactive effect whatever. Further, the amendment protects only a "coined or peculiar word" or "unique symbol." Descriptive or geographical words, and personal names, which have been traditionally outside the scope of trade-mark protection, will not be protected in Massachusetts either under this amendment, or at common law.

${ }^{66}$ In its original version it was House Bill No. 656, introduced by Mr. Hurwitz in 1947. 67 Ibid.

68 Prepared by members of the Boston Bar and representatives of various organizations such as the Retail Board of Trade, Better Business Bureau, and Associated Industries of Massachusetts, and presented in connection with the only legislative hearing on House Bill No. 656 before the joint committee on Mercantile Affairs of the Massachusetts House and Senate.

${ }^{69}$ Id. at 3. (Emphasis added.) 
In other words, it was emphasized that the dilution concept in the proposed statute should not apply to all kinds of trademarks or trade names but only to those which could be recognized as unique symbols or, at least, as coined or peculiar words. The House of Representatives, in March 1947, approved the proposed bill as so limited. ${ }^{70}$ However, the bill as passed by the Senate changed the House bill by eliminating any reference to "peculiar" or "unique" marks and by substituting therefor the exact language which became the law in Massachusetts upon the Governor's signature thereto in May $1947,{ }^{71}$ and which has served as the prototype for the Mlinois, New York, and Georgia statutes. As passed, the statute broadly refers to any trade name or trademark and provides for protection thereof against dilution even in the absence of competition or confusion as to the source of goods or services.

It has, however, already become quite clear that even under the statute as now worded, there can be no "dilution" unless the mark or name involved has acquired a sufficient reputation and celebrity to be included in the class of names which led to the enactment of the statute, such as "Kodak," "RCA," "Philco," and others, even though such name may not necessarily be a newly coined word. In other words, the courts in Massachusetts, as elsewhere, have little patience with the "cry of dilution," as the United States Court of Appeals for the First Circuit has called it, ${ }^{72}$ if raised by someone who has adopted an undistinctive trademark and seeks enlarged protection-sometimes even against a direct competitor-through an ill-founded reliance on the antidilution statute. The first case in which the Massachusetts statute was interpreted involved the trade name "Food Fair," which, as such, certainly can make no clain to being a particularly unique trademark. ${ }^{73}$ Judge Wyzanski took the unusual step in that case of hearing testimony by a Boston attorney on the statutory background of the antidilution act. ${ }^{74}$ In giving himited relief to the plaintiff, the court expressly stated that it did not have to decide the question whether a plaintiff miglit be entitled to relief in a case where there might be "absolutely no likelihood of deception" or in a case involving goods or services "unrelated to supermarkets." In In other words, since the case before the court involved use of the identical name on identical merchandise in territory into which

\footnotetext{
70 Commonwealth of Massachusetts, House No. 1865, March 17, 1947.

71 Mass. Laws ANn. c. $110 \$ 7$ A (1954).

72 Pro-Phy-Lac-Tic Brush Co.v. Jordan Marsh Co., 165 F.2d 549 (1st Cir. 1948), affirming
} 70 F. Supp. 1012 (D. Mass. 1947).

73 Food Fair Stores, Inc. v. Food Fair Inc., 83 F. Supp. 445,79 U.S.P.Q. 114 (D. Mass. 1948), aff'd, 177 F.2d 177 (1st Cir. 1949). The early Massachustts cases are discussed in Pattishall, The Case for Anti-Dilution Trade-Mark Statutes, 43 TradE-MARK Rep. 887 (1953).

74 Food Fair Stores, Inc. v. Food Fair, Inc., 83 F. Supp. 445, 450, 77 U.S.P.Q. 265, 270

(D. Mass. 1948).

75 Id. at 451,77 U.S.P.Q. at 271 . 
the plaintiff had not yet fully expanded, no case of dilution as to difference in goods was present and Judge Wyzanski's decision, as well as that of the appellate court, ${ }^{76}$ is far from holding that a name such as "Food Fair" might be entitled to protection against use on totally unrelated goods or in the absence of any likelihood of confusion. ${ }^{77}$

In The Pep Boys, Manny, Moe and Jack v. Pilavin, ${ }^{78}$ the antidilution statute was referred to by the Massachusetts district court solely for the purpose of pointing out that, contrary to earlier Massachusetts cases, no actual market competition was any longer required before a finding of unfair competition could be made. In other words, it was held that plaintiff's trademark and trade name had become known in Massachusetts and that plaintiff was therefore entitled to preemptive protection in that territory. Moreover, the court noted that protection based on plaintiff's reputation in the area would, in all probability, have been granted even under the Massachusetts law prior to the enactment of the antidilution statute. Similarly, the plaintiff in Libby, McNeill \& Libby v. Andrew G. Libby ${ }^{70}$ prevailed against defendant's use of the name "Libby" in connection with food products on the ground that plaintiff's name acquired a secondary meaning in Massachusetts and had been registered there. The antidilution statute was referred to solely for the purpose of emphasizing that no direct competition between the parties was required. Moreover, the defendants were enjoined only from using the name in connection with food products, and even with regard to those products were permitted use of the name if qualified by adding their first name or middle initial to it. This case certainly does not represent a special antidilution problem. Reference to the statute was also made by the Supreme Judicial Court of Massachusetts in a case where plaintiff sought protection of the common word "Parkway" as used in connection with the garage business. ${ }^{80}$ The case involved direct competition between the parties but relief under the antidilution statute was denied on the ground that the word "Parkway" had not even acquired a secondary meaning as designating the plaintiff's place of business, and that the latter's rights had not been enlarged by the antidilution statute. ${ }^{81}$

\footnotetext{
76177 F.2d 177 (1st Cir. 1949).

${ }^{77}$ In another "Food Fair" litigation, which arose in the District of Columbia, Food Fair Stores, Inc. v. Square Deal Market Co., 109 F. Supp. 637 (D.D.C. 1952), aff'd, 206 F.2d 482 (D.C. Cir. 1953), cert. denied, 346 U.S. 937 (1954), the plaintiff was entirely unsuccessful because of prior use of the name by defendant in the particular area imvolved; the Massachusetts case, supra note 73, was distinguished on the facts.

7883 F. Supp. 445, 77 U.S.P.Q. 265 (D. Mass. 1948).

79103 F. Supp. 968, 93 U.S.P.Q. 179 (D. Mass. 1952).

80 Mann v. Parkway Motor Sales, Inc., 324 Mass. 151, 85 N.E.2d 210 (1949).

81 The highest Massachusetts court had held, even before this case, in Healer v. Bloombcrg Bros., 321 Mass. 476, 73 N.E.2d 895 (1947), that plaintiffs, who bad done business under the firm name "William Bond \& Son," were entitled to enjoin defendants from using the name
} 
Perhaps more significant than the just-mentioned cases, which expressly refer to the antidilution statute, is the only other Massachusetts case which went to the Court of Appeals for the First Circuit and includes a rather characteristic discussion of the dilution theory, even though the statute itself had come into effect after the lower court's decision had been handed down. In Pro-phy-lac-tic Brush Company v. Jordan Marsh Company, ${ }^{82}$ plaintiff used the word "Jewelite" on hair brushes and sought to enjoin defendant froin using "Gemlite" on toilet sets. The district court, without as much as mentioning any question of "dilution," merely held that the two terms were not confusingly similar and dismissed the complaint. The court of appeals, however, which decided the case early in $1948^{83}$ after the antidilution statute had become effective, entered into an interesting discussion of the plaintiff's contention that the "memory value" of its trademark "Jewelite" had been diluted. To this the appellate court-and quite correctly, it is submitted-replied: ${ }^{84}$

The answer to this contention is that the "dilution doctrine," as it may be called, operates to extend the protection of the trade-mark law to the situation presented when similar marks are used on dissimilar goods, and that it has no application when the question is whether the marks being used on goods of substantially the same descriptive properties are similar enough to cause confusion in the minds of consumers with respect to the source of the goods. That is to say, the statute, 15 U.S.C.A. $\S 96$, affords protection to the owner of a registered trade-mark against the use by others without his consent of reproductions, counterfeits, copies or colorable imitations of his inark on "merchandise of substantially the same descriptive properties" and the dilution doctrine operates to give the owner of a registered trademark the same protection against the use of his mark by others on goods of different descriptive properties. Thus the doctrine may be invoked to protect the owner of a mark for automobiles and airplanes from the use by another of a very similar mark for radio tubes (Wall v. Rolls-Royce of America, Inc., 3 Cir., 4 F.2d 333) or to protect the owner of a mark for fountain pens and similar writing instruments from the use by another of a very similar mark for safety razor blades. L. E. Waterman Co. v. Gordon,

"Bond Jerwelers," both parties having been in the jewelry business. The word "Bond" was held to have acquired a secondary meaning and the court expressly found that there was competition between the parties so that there was no occasion in any way to refer to the antidilution act.

In its most recent decision involving a suit by a plaintiff wholesaler, Monroe Stationers and Printers, Inc. v. Munroe Stationers, Inc., 332 Mass. 278, 124 N.E.2d 526 (1955), in which a retailer used the naine "Munroe Stationers, Inc.," the Supreme Judicial Court affirned the lower court in granting relief on the ground that some actual confusion had been shown, that plaintiff's name had acquired a secondary ineaning, and that it would have been easy for defendant to have chosen a different corporate name. In view of these facts, it was held unnecessary to decide whether plaintiff might also have been entitled to injunctive relief under the antidilution statute in an area where the plaintiff had not planned to open a branch.

8270 F. Supp. 1012 (D. Mass. 1947).

83165 F.2d 549 (1st Cir. 1948).

84 Id. at 553. 
2 Cir., 72 F.2d 272. But the marks must be deemed similar before the doctrine has any application. Therefore, since we agree with the district court that the marks under consideration are not similar withm the meaning of the statute, whereas the goods upon which they are used undoubtedly are of the same descriptive properties, it follows that the dilution doctrine has no bearing upon the situation with which we are here concerned.

More than that, the court pointed out that plaintiff's mark was hardly capable of dilution because the word "jewel" was already diluted when plaintiff first adopted "Jewelite" as a trademark. We submit that the answer would have been exactly the same if the antidilution statute had been expressly referred to because the two most important prerequisites for any application of the dilution theory were absent in the case; that is, it neither involved a unique trademark worthy of this special protection nor was there any occasion for its application in any event because both parties used their respective marks on almost identical goods.

The same is true of the most recently reported Massachusetts case in which the antidilution statute was expressly invoked-and rejected. ${ }^{85}$ The plaintiff there was manufacturing a laminated cellophane tape under the name "Zip-Tape," and had secured a federal registration for that mark. Defendant manufactured machines for packaging loose material in cellophane bags, such as potato chips, and called his machine "Zip-Corder." Plaintiff alleged that defendant's use of the syllable "Zip" diluted his distinctive trademark. Judge Aldrich held, however, that it was "not clear" how far the antidilution statute went beyond the Lanham Act's requirement of a finding of at least a possibility of confusion, and that in this case no dilution could be found in any event because plaintiff had "little appropriatable reputation" and particularly because of the complete lack of distinctiveness of the syllable "Zip." The court correctly said:"8

I might not be averse to extending protection against this sort of dilution in the case of a fanciful or "strong" mark whose character was solely or primarily due to the owner's endeavors. However, it is another thing to extend it to a mark which is hypersuggestive and by its own nature highly fragile, if not autophagous.

And again, citing the Jewelite case:

Where dilution of the sort here objected to is inherent in the nature of the mark because of the suggestive meaning of a component word, I will not hold that a non-confusing and otherwise proper use of that word in a different mark can be enjomed simply because it may increase plaintiff's instability ... . If a party chooses an unstable mark, he must accept the consequences.

85 The Dobeckmun Company v. Boston Packaging Machinery Co., 107 U.S.P.Q. 350 (D. Mass. 1955), corrected at 109 U.S.P.Q. No. 7, p. II, and No. 10, p. III.

86 Id. at 352 . 
Following his decision in the "Zip" case, Judge Aldrich had another occasion in the very recent case of Esquire, Inc. v. Esquire Slipper Manufacturing Co., ${ }^{87}$ on March 16, 1956, further to pass upon the applicability of the antidilution statute in a case in which the publisher of "Esquire" Magazine sought to enjoin a manufacturer of men's slippers from using the name "Esquire" as part of its corporate name. While the court recognized, of course, that "Esquire" as a name for a magazine had acquired valuable good will and, to some extent, sold not only advertising but also what was called "commercial blessing" for certain fashion products, it refused to hold that the word "Esquire" was sufficiently unique to mean only one thing to the general public, i.e., "Esquire" Magazine. On the contrary, the court stressed the fact that sone 5000 persons throughout the country had adopted the name "Esquire" conumercially, and that the name had been attached to hundreds of services and goods with which the plaintiff's magazine had no connection. The court referred to the fact that the name had been registered before plaintiff's trademark was obtained for men's fashions, toilet articles, watches, and numerous other articles. It held, therefore, that despite plaintiff's efforts to "police" the name "Esquire" for the purpose of avoiding a charge of constructive abandonment ${ }^{88}$ the name was not so unique or famous as to be entitled to protection against use by a manufacturer of men's slippers. With regard to the specific charge of dilution, Judge Aldrich said: ${ }^{88}$

There may also be an injury which some courts, and the Massachusetts statute, term dilution. While dilution has been described as the whitting away of a special meaning through use by another, this is too broad a definition. I believe there must be at least some "likely confusion," and that where there is none, a person proceeding on the strength of his own title is not guilty of dilution. Manufactured words may have a special individual meaning, and so may a combination of common words. But I will not hold that a single or solitary word in common use can be entirely appropriated from the public domain so that other users have no right.

The plaintiff, accordingly, must show at least a recognizable possibility of confusion.

So much for the Massachusetts cases which liave thus far interpreted the antidilution statute. Four major conclusions may be drawn from this analysis:

87139 F. Supp. 228, 109 U.S.P.Q. 30 (D. Mass. 1956).

88 See text beginning at note 109 infra. In Francis H. Leggett \& Co. v. Premier Packing Co., Inc., 140 F. Supp. 328 (D. Mass. 1956), broad relief was given to the owner of the registered trademark "Premier" with regard to both intra- and interstate commerce; in connection with intrastate commerce in Massachusetts, the court placed express reliance on the Massachusetts Antidilution Statute, althougl it would seem that if the court bad applied the doctrine laid down by Judge Wyzanski in Cole of California, Inc. v. Collette of California, Inc., 79 U.S.P.Q. 267 (D.Mass. 1948), the same result might have been reached without reliance on that statute. s0 139 F. Supp. at 232-33, 10 U.S.P.Q. at 34-35. 
1. There is no room for the dilution theory-nor any need for itunless the defendant is engaged in a totally dissimilar business or operates in an entirely different territory.

2. The dilution theory will soon be discredited in Massachusetts and elsewhere if resorted to by the users of trademarks which, as the circuit court of appeals in the Jewelite case said, are already "diluted" when first adopted and which do not live up to the standard of uniqueness as did such marks as "Kodak," "Odol," and others.

3. National and international fame and uniqueness may be acquired not only in names that are arbitrarily coined, such as "Kodak," but also in extraordinary cases in famous family names, such as "Tiffany." On the other hand, it is interesting to note that section 27 of the British Trade Marks Act of 1938 and section 38 of the Indian Trade Marks Act of 1940 limit the broader concept of so-called "defensive" registrations, which both statutes permit, to "invented" words."

4. Judge Aldrich's observation in the Esquire case that the plaintiff in a dilution action must still show "a recognizable possibility of confusion," may be subject to challenge, at least as a matter of theoretical approach. While this may have been true under the specific facts of the Esquire case, no showing of "confusion" of any sort, no matter how nebulous or farfetched, should be required where a party merely adopts soniebody else's famous trademark for the obvious reason of capitalizing upon the reputation and goodwill created by its owner. As was well stated by the authors of a comprehensive recent review of the law of trademarks and unfair competition: ${ }^{91}$

90 The statutes read: "Where a trade mark consisting of any invented word has become so well-known as respects any goods in relation to which it is registered and has been used, that the use thereof in relation to other goods would be likely to be taken as indicating a connection in the course of trade between those goods and a person entitled to use the trade mark in relation to the first-mentioned goods, then ... the trade mark may on application in the prescribed manner by such proprietor be registered in his name in respect of those other goods as a defensive trade mark ...."

This section received a very narrow construction in In the Matter of an Application by Ferodo, Ltd., 62 R.P.C. 111 (1945), in which it was held, in effect, that the section was more or less limited to marks which had become "household words." The analogous provision of the Indian law was recently criticized in a paper by K. S. Shavaksha, former Registrar of Trademarks in Bombay, Principle Underlying Defensive Registration, 46 Trademark Rep. 266 (1956). It was suggested in this paper that defensive registrations of this sort sbould not be necessarily limited to "invented" words. The recent REPORT OF THE COMMMITTEE APPOINTED aY THE Atrorney-General of THE CoMmonwealte (of Austrahia) to consider alterations in the Australian Trade Marks Law (which resulted in the Trade Marks Act of 1955), while recommending the introduction of the concept of defensive trademarks into the Australian Act, also recommended that the limitation to "invented" words be climinated (p.9).

91 Developments in the Law-Trade-Marks and Unfair Competition, 68 HARv. L. REv. 816, 851-52 (1955). 
Apparently, this protection has thus far been limited to marks that have gathered about them connotations of quality that miglit be destroyed in the public mind by the use of the.marks on products or services of an inferior quality, or of such a nature that no comparable prestige could attach to them. It might be argued that this protection should be extended to any coined or highly distinctive mark which has no connotations other than those attaching to it by virtue of its association with the owner's product, since there is no countervailing public policy in favor of allowing its use by others.

$B$. New York The only reported New York case which directly applies the recent state antidilution statute is entirely in line with the above conclusions. ${ }^{22}$ In that case the plaintiff sought to enjoin defendant from using the name "Peerless Electric," these two words being part of plaintiff's own corporate name. The case lacked all the elements of a dilution action, since the name involved was a rather undistinctive name in common use, "Peerless," and since the parties operated in closely related fields. The court, however, buttressed the granting of injunctive relief by expressly referring to the public policy of the State of New York as expressed in the antidilution statute, although the same result would clearly have been reached even in the absence of the act. ${ }^{93}$

C. Other Jurisdictions (New Jersey, Pennsylvania and California) Where attempts have been made in recent years to apply the dilution theory in other jurisdictions which have not yet adopted antidilution legislation, they were usually equally unsuccessful because "the cry of dilution" was raised in situations in which it clearly should not be heard. In the Third Circuit, Judge Forman held in Q-Tips, Inc. v. Johnson \& Johnson ${ }^{94}$ that the words "Johnson's Cotton Tips" constituted an infringement of plaintiff's trademark "Q-Tips" and therefore refused to pass upon plaimtiff's amended cause of action pleading dilution of the "Q-Tips" mark through the defendant's use of the word "Tips." The court rightly said:" (1954)

92 Peerless Electric Company v. Peerless Electric, Inc., 135 N.Y.S.2d 885, 103 U.S.P.Q. 283

93 More recently still, the antidilution act was referred to in an action by a plaintiff using the word "Living" on girdles, brassieres and gloves, against a defendant's use of the same word for cosmetics. International Latex Corp. v. Revlon Products Corp., 148 N.Y.S.2d 304 (1955). The court denied a motion for preliminary injunction because it did not appear from the papers as filed that plaintiff's reputation was in any way endangered by defendant's use of the word, and that the alleged "whittling away" of the uniqueness of plaintiff's nark was an issue that should not be decided without trial on the inerits. For another recent case in which the antidilution statute was referred to in New York in a different context and for a different purpose, see Wertheimer v. Milliken, 123 F. Supp. 358 (D.N.Y. 1954), discussed in text beginning at note 169 infra.

94 108 F. Supp. 845 (D.N.J. 1952), aff'd, 206 F.2d 144 (3d Cir. 1953), cert. denied, 346 U.S. 867 (1953).

95108 F. Supp. at 866 . 
The "dilution" theory has been applied where the products of the parties have been dissimilar or their territories are different ....

Protection is afforded to the owner of a trade-mark against the use by others of imitations of his mark on a product similar enough to cause confusion in the minds of the customers as to the source of the goods through the ordinary redress for infringement without resort to the doctrine of "dilution." See Pro-Phy-Lac-Tic Brush Co. v. Jordan Marsh Co., 165 F.2d 549 (1st Cir. 1948). In the instant case the products are the same and the doctrine of "dilution," as projected by the plaintiff, appears to liave no application.

In Pennsylvania the dilution theory was invoked by the plaintiff in Sears, Roebuck \& Co. v. Johnson. ${ }^{96}$ The plaintiff had used the name "All-State" for automobile accessories and insurance services. Judge Kirkpatrick, in rejecting the dilution theory, said: ${ }^{97}$

In the absence of any possibility of loss througl competition on the part of the defendant, the plaintiff seeks to support its right to an injunction upon two theories, which may be referred to as "disrepute" and "dilution."

There remains the "dilution" theory which is, im substance, that unless the plaintiff can prevent the use of his trade name by anyone in any kind of business it will lose some of its advertising value. I doubt that this theory has crystalized into law but, in any event, it would have to be limited rather strictly to fanciful, unique and ineaningless coined words. As pointed out in the Certain-Teed case, supra, the word "certain-teed," while not to be found in the dictionary, is by no means meaningless. So with "Allstate." The word can be used in conversation or literature as applied to any nationwide business or activity, without the slightest sense of incongruity. Besides, the defendant does not actually use the plaintiff's coined word but its components, which are two ordinary English words, and which could be descriptive of a business like his if his course of instruction included rules and traffic regulations of states other than Pennsylvania. It is hard to see how the plaintiff could prevent the use of the words "all state" in connection with a book of road maps covering the United States or a pamphlet containing the automobile laws of all the states. It seems to me that when a person chooses a trade name which has a perfectly intelligible meaning and can be used naturally in all sorts of connotations and is, therefore, inevitably subject to "dilution" - in fact already diluted when chosenthe person who adopts it, while he can, of course, restrain its use on various grounds under the principles heretofore discussed, cannot very well stand upon the sole theory of "dilution."

The United States Court of Appeals for the Third Circuit reversed the district court, ${ }^{98}$ not on any theory of dilution, but solely on the ground that the plaintiff had built up a substantial goodwill and secondary meaning

06121 F. Supp. 955, 101 U.S.P.Q. 243 (E.D.Penn. 1954).

07 Id. at 958,101 U.S.P.Q. at 245.

08 Sears, Roebuck and Co. v. Johnson, 219 F.2d 590 (3d Cir. 1955). 
and that confusion was likely to result in the public mind because of the close association of plaintiff's goods and services and defendant's school. The appellate court held that plaintiff had made out "a very clear case of trade name infringement" and that under ordinary principles of unfair competition relief slould be granted because of likelihood of confusion.

It thus appears that the higher court saw no necessity to as much as mention the dilution theory, nor to pass or comment upon the district court's observations with regard to dilution which, when considered in isolation, would appear to be quite sound.

Cases of this sort would further seem to prove that where the "cry of dilution" may be effectively raised (as it was in the same circuit, although not under the label dilution, in the famous Rolls-Royce case), ${ }^{99}$ an equity court may well grant relief in the absence of a showing of any speculative type of confusion and in the absence of a specially enacted antidilution statute.

Our last observation would seem to be peculiarly applicable to a state such as Califorma, in which the dilution theory was applied, inter alia, in the famous Stork Club litigation, ${ }^{100}$ even though there is no antidilution statute. California has, however, a very general statutory prohibition of unfair competition in section 3369 of the Civil Code, which in part provides:

Any person performing or proposing to perform an act of unfair competition within this State may be enjoined in any court of competent jurisdiotion. ... [U]nfair competition shall mean and include unfair or fraudulent business practice and unfair, untrue or misleading advertising.

As rightly pointed out by the court in the recent case of Haeger Potteries v. Gilner Potteries, ${ }^{101}$ this language is sufficiently broad to cover an unlimited number of unfair business practices, including the tort of dilution. ${ }^{102}$ It is not surprising then that even in the absence of a special antidilution statute, the concept is sufficiently well established in California to justify the recent dictum by the United States Court of Appeals for the Ninth Circuit in a case involving the trade name "Fairway": 103

It is true that unfair trade may result from the dilution of the business good will in ways not connected directly with the possible loss of a sale through deception or confusion....

\footnotetext{
99 Wall v. Rolls-Royce of America, 4 F.2d 333 (3d Cir. 1925).

${ }^{100}$ Stork Restaurant v. Sahati, 166 F.2d 348 (9th Cir. 1948). 101123 F. Supp. 261, 267 (D. Cal. 1954).

${ }^{102} \mathrm{Cf}$., with regard to the California law generally, Netterville, California Law of Unfair Competition: Unprivileged Imitation, 28 So. CALIF. L. REv. 240 (1955).

103 Fairway Foods, Inc. v. Fairway Markets, Inc., 227 F.2d 193, 196 (9th Cir. 1955).
} 
D. Application of the "Dilution" Concept by the Commissioner of Patents in Registration Proceedings As previously mentioned, it is true that, as George Middleton observed, ${ }^{104}$ the registration statute of 1946 does not expressly embody the concept of dilution. It is at least doubtful, too, as Daphne Robert (Leeds) pointed out in The New Trademark Mamal, ${ }^{105}$ whether the language of the statute dealing with infringement is broad enough to include the theory of dilution in the Schechterian sense. But there is a rather indirect approach by which the concept has found a small degree of statutory recognition in section 2 (a) of the act. Under that section, registration shall be refused of marks which may "falsely suggest a connection with persons living or dead, institutions, etc." At least two instances have been found in which famous marks have been rejected on the basis of this language for totally dissimilar goods. In Ex parte Galter ${ }^{100}$ an applicant sought to register the word "Kodak" for pyrophoric cigar and cigarette lighters. In rejecting the application because of registrations of the famous "Kodak" trademark for totally dissimilar goods, the Examinerin-Chief pointedly observed: ${ }^{107}$

It is seldom that a newcomer attempts to bodily adopt an arbitrary and coined trade-mark as well-known and as well-advertised as the one in issue. ... It is difficult to find any reason in this case for applicant wanting to copy the name "Kodak" except the desire to profit from another's good will.

It will be noted that this mark was not even published for opposition but was rejected on this basis, ex parte. ${ }^{108}$ Subsequently, the same question was raised in a contested case, an opposition proceeding brought by the owner of the famous "Copacabana" night club against an applicant for registration of the identical word for perfumes and other cosmetics. ${ }^{100}$ In sustaining the opposition, Assistant Commissioner Leeds expressly referred to the name "Copacabana" as a nationally, if not internationally, renowned name and suggested that the Patent Office should refuse to register such celebrated names on the theory that under section 2 (a) their registration would falsely suggest a trade connection with a well known person or business. Although not basing the decision on dilution in so many words, but on like-

104 See note 59 supra.

105 Robert, The New Trade-Mark Manuax, A Handbook on Protection of TradeMarks IN INTERSTATE COMMERCE 163 (1947).

10696 U.S.P.Q. 216, 43 Trade-MarK REP. 317 (1953).

107 Ibid.

108 This problem is discussed further in Derenberg, The Patent Office as Guardian of the Public Interest in Trade-Mark Registration Proceedings, 14 Law \& ConTEMr. ProB. 288 (1949). 100 Copacabana, Inc. v. Breslauer, 101 U.S.P.Q. 467, 44 TradE-MARK REP. 987 (1954). The same principle was recently apphed by the Commisioner of Patents in John Walker \& Sons, limited v. The American Tobacco Company, 110 U.S.P.Q. 249 (1956), where it was held that use by the applicant of the famous name "Johnnie Walker" on cigarettes might "falsely suggest" a trade comection with opposer. 
lihood of confusion in the sense of the possibility of a falsely suggested trade connection, Commissioner Leeds cited and relied upon most of the court cases in which the dilution theory had first been invoked. ${ }^{110}$

\section{III \\ "DEATH OF A TRADEMARK"}

The four state antidilution statutes speak of dilution of "the distinctive quality of a trade name or trademark." 111 While there have been no reported decisions on the point in any one of the four states, it would seem clear that this language is broad enough not only to include the traditional case of "dilution" heretofore discussed, in which the umiqueness of a trademark may be impaired as a result of trademark use by others of the same mark on totally unrelated goods, but might also be resorted to to give some measure of relief in the far more serious and frequent cases of dilution through public use leading to a gradual loss of distinctiveness of a well known trademark. In other words, loss of the distinctive quality of a trademark through development of the mark into a generic term, or what the Trademark Act of 1946 unhappily terms "a common descriptive term," may constitute a form of dilution which might well result in a total loss of all trademark rights unless the trademark owner is given some redress by statute or by the courts to prevent this form of dilution. In the recently published guide-book on "Trademark Management," a comprehensive chapter is devoted to the policing of trademarks which have become so popular as almost to assume the status of household words. ${ }^{112}$ It is pointed out that constant vigilance is required to police the proper use of trademarks both by the owner's own sales staff and in publications and writings of others. Indeed, as may be gathered from Mr. Bayol's chapter, the checking and policing of proper use of famous marks, such as "Kodak," "Coke," "Technicolor," "Band-Aid," and innumerable others, has become more or less a daily chore of a staff of experts who will send out a standard forn letter, courteously calling attention to the misuse of the trademark and invoking the aid of the recipient to correct the mistake and avoid similar misuse in the future. It is of course, a known fact that in many such instances the recipient of such letter, even if it be a dictionary or periodical publisher, will cooperate; but the question must be asked, what legal remedies, if any, are available to the trademark owner if no cooperation, but further misuse, is forthcoming and at what point may our courts reach the conclusion that, as a result of continuous nnisuse, the trademark itself

110 Copacabana, Inc. v. Breslauer, 101 U.S.P.Q. 467, 468, 44 Trade-MaRk Rep. 987, 988 (1954).

111 See note 7 supra.

112 Bayol, Policing of Tradentarks, UntTed States 'Trademark Ass's, A GUID for BustNESSMIEN, c. V (1955). 
has lost its significance? In other words, what should be the next step in the type of case to which reference was made in the late Mr. Mencken's work, The American Language, ${ }^{113}$ where the B. F. Goodrich Company brought to the attention of "Life" Magazine the fact that it claimed exclusive trademark rights in the word "Zipper," which it had adopted in 1923, and where, rather than complying with the Goodrich Company's request not to treat the word as a common noun, the editors of the magazine were quoted to have answered as follows: ${ }^{114}$

Life's apologies, but the Goodrich Company must be aware that its trademark has passed into the English language.

Would the publisher of the magazine be liable in a civil action on the basis of "dilution" and "injury to the distinctive quality of the owner's trademark"? Is it true, as was recently asserted in a leading article in the trade magazine, "The American Press," that the unhappy fate of the "Deepfreeze" product to which the author of the article refers was attributable in part, at least, to the fact that its name had become a generic term and that, "legally, a company has the right to sue for damages when its trademark is used improperly"? ${ }^{115}$ The author of the article continued:110

But most companies hesitate to do this because they do not want to cause bad feeling. Instead, they often write little notes to the editor asking for his cooperation and pointing out the error in the use of a name. These notes may be couched in the inost polite phraseology, but actually they are a cry for mercy on the part of a businessman who reahzes that his trademark and his business can be "lower-cased" or "misspelled" to death.

I suggest that the first quoted sentence probably reflects wishful thinking, rather than a correct statement of our present law, at least, our federal law, and may at best be proven to be true some time in the future in one of those states which have enacted antidilution statutes.

Our Trademark Act of 1946 is not only silent on this point but has, if anything, made well known trademarks more vulnerable than before to an attack on the basis of genericness. This disconcerting conclusion is based on reading and interpreting together three different sections of the act of 1946, two of which were included at the last moinent before the act was passed. As the law now stands, a registered mark which might otherwise qualify for incontestabihty, will remain subject to cancellation at any time, according to section $14(\mathrm{c})$, if it becomes "the common descriptive name

113 Untred States Trademark Ass's, Trademark Management, A Guide for BusinessMaEN, Supp. I, p. 344, n.4 (1955).

114 Ibid, reply of the editors to a letter protesting the use of the word "zipper" as a common noun, Jan. 3, 1938.

115 Death of a Trademark, The American Press, Feb. 1952, p. 20.

116 Ibid. 
of an article or substance upon which the patent has expired" and this is amplified by a proviso in section 15.4 , so as to specifically state that no incontestable riglit shall be acquired in a mark "wlich is the common descriptive name of any article or substance patented or otherwise." In section 45 , loss of trademark significance is referred to as one of the instances of constructive abandonment if this occurs as a result of "any course of conduct of the registrant, including acts of omission as well as commission." But low about those cases in which the loss of distinctiveness cannot be traced to any act of omission or commission on the part of the trademark owner? If the innumerable letters which we are accustomed to write, objecting to reference to our clients' trademarks without quotation marks or without capital letters, or their inclusion in dictionaries, cannot be followed up as a matter of law by an infringement suit, then is it safe to assume that, as a mere result of sending hundreds of letters of protest and objection, we may defend our clients' trademarks against forfeiture on the ground that there lias been no known act of omission on the owners' parts but, on the contrary, extreme vigilance, which many times is exercised for no other real purpose than to create a respectable body of proof for the purpose of avoiding a charge of constructive abandonment in the future?

In other words, is it true that the trademark owner will not be held to lave lost his trademark in the absence of any improper conduct on his part, such as was found to be present in the "Shredded Wheat," "Cellopliane," and "Aspirin" cases, ${ }^{117}$ or is our present law still reflected in the muchquoted dictum by Judge Augustus Hand in the "Cellopliane" case in whicl he said: ${ }^{118}$

It, therefore, makes no difference what efforts or money the $\mathrm{Du}$ Pont Company expended in order to persuade the public that "cellophane" means an article of Du Pont manufacture. So far as it did not succeed in actually converting the world to its gospel it can have no relief.

Judging from the latest pronouncement on this point by Judge Learned Hand, in January 1956, we may indeed lrave to conclude that the "Cellopliane" dictum is presently considered the law of the land. In his opinion in Artype, Inc. v. Zappulla, ${ }^{119}$ Judge Hand specifically observed, quoting the "Celloplane" and other cases for this proposition, that "no care or

117 Kellogg Co. v. National Biscuit Co., 305 U.S. 111 (1938); DuPont de Nemours \& Co. v. Waxed Products Co., 85 F.2d 75 (2d Cir. 1936), modifying 6 F. Supp. 958 (EDN.X. 1934), cert. denied, 299 U.S. 601 (1936); Bayer \& Co., Inc. v. United Drug Co., 272 Fed. 505 (S.D. N.X.1921).

11885 F.2d 75, 81 (2d Cir. 1936).

119228 F.2d 695, 108 U.S.P.Q. 51 (2d Cir. 1956). 
expense designed to preserve a mark, originally valid, will protect it, if it has in fact come to be only descriptive." "

Commenting upon the dictum in the "Cellophane" case, the late Frank I. Schechter had said: ${ }^{121}$

Just how, under modern conditions of production, advertising and distribution, any complainant could "succeed in actually converting the world to its gospel" so that it can obtain relief from trade-mark piracy is not clear. We are confronted with this paradox that the very creation of any real hold on the public mind through trade-mark advertising and merchandising must, by such reasoning, in and through itself, automatically involve the self-destruction of the mark.

As a matter of federal law, this is as true today as it was in 1937 and there would seem to be only two broad approaches in which a fair solution to this most vexing of all trademark problems can be found: either our federal statute should include a provision to the effect that a cause of action for trademark infringement would he against any misuse of a trademark, not only im a commercial but in a noncommercial or collateral way as well, or we should attempt to bring our judge-made law into accord with the practice in almost all other countries, that is, not to declare a trademark to have become generic in the absence of a complete loss of all trademark significance.

With regard to legislative relief, we recently came within striking distance of a solution. Since it seems so extremely doubtful whether a trademark owner under our present law may go beyond letter writing and actually sue, for example, a dictionary publisher who refuses properly to indicate the trademark significance of a certain term, it was sought to include an amendment in the act of 1946 which would be broad enough to enable trademark owners to put some teeth into the usual pleas for voluntary compliance with the owner's rights. When the Hawkes Bill ${ }^{122}$ was introduced in 1947, it included an amendinent to section 32.1(a) which provided for a cause of action for infringement against a person who used a registered trademark in a way "which is likely to cause the registered mark to lose its significance as an indication of origin." The first Wiley Bill, ${ }^{123}$ in section 22 (c), nore specifically provided that any person should be liable in

120 Equally disturbing is Judge Hand's comment in American Chicle Co. v. Topps Chewing Gum, Inc., 208 F.2d 560, 562 (2d Cir. 1953), where he said: "It is reasonable to believe that the fabulous sum- $\$ 11,000,000$-that has been spent in 'publicizing' the plaintifi's nuggets as 'Chiclets' has fixed the word in the minds of many buyers as meaning no more than a candy coated gum nugget; and to some degree destroyed it as a trade-mark. That is a peril to which all such advertising is subject; its very success may prove its failure." (Emphasis added.)

121 Trade Morals and Regulation: The American Scene, 6 FordeaM L. REv. 190, 202-04 (1937).

122 S. 1919, 80th Cong., 1st Sess. (1947).

123 S. 2540, 83d Cong., ist Sess. (1953). 
a civil action who employed a registered mark in commerce "otherwise than as a trade or service mark, in such manner as to be likely to cause the mark to lose its significance as a mark." ${ }^{124}$ When the Wiley Bill was reintroduced in the second session of the 83rd Congress, ${ }^{125}$ section 23 (c) of the bill still included the identical provision. However, during the hearings on the bill, in March 1954, objections to this amendinent began to be raised. When John T. Love, one of the sponsors of the Wiley Bill, explained the purpose of this amendment to Senator Wiley by pointing out that there were times when a trademark might lose its significance due to no fault of the trademark owner, the following significant colloquy occurred between Mr. Love and the Chairman: ${ }^{128}$

Mr. LovE: Many, many times I have heard the very valuable trade-mark "Kleenex," owned by International Cellucotton, used in a generic sense over the radio by comedians and people in skits; soap operas, I think they are called.

And consequently, on page 16 of S. 2540 , section 23 of the bill, one of the features of the proposed revision of section 32 , subsection 1 , is to give a person, a trade-mark owner, the right to proceed against a person who shall employ a registered mark in commerce otherwise than as a trade-mark or service mark in such manner as to be hikely to cause the mark to lose its significance as a mark.

This would enable them to proceed agamst these people who had destroyed the significance and distinctiveness of his trade-mark.

SENATOR WILEX: Wait a minute, now. We have got to have a little freedom of speech. You fellows who have trade-marks wouldn't want to kill some of the humor that we need so much, would you? What do you suggest about it? You mean to say that here today, if we were to make up a song about Kleenex and sing it on the radio, Kleenex might lose its mark, have any tendency to lose its mark?

Mr. Love: One isolated case like that wouldn't do it.

SENATOR WILEY: You mean my voice wouldn't be appropriate? No, no. We want to be sensible in this stuff, and we mustn't make our laws anything but a reflection of common sense. And if you feel that once you got a mark for a certain commodity, anyone, without any desire to injure, of course, commits a fraud, uses that mark in common speech or over the radio or otherwise, he could, by such act, deprive me of my trade-mark. Is that the law?

Mr. Love: Well, the Supreme Court seemed to think it was in the Aspirin and Cellophane cases.

124 Id. at 16.

125 Amendment in the nature of a substitute to S.2540, 83d Cong., 2d Sess. (1954).

126 Hearings Before the Subcommittee of the Senate Committee on the Judiciary, 83rd Cong., 2d Sess. 52 (1954). 
The Chairman's misgivings were shared, strangely enough, by the State Department which rather unexpectedly objected to the proposed amendment on the ground that its adoption may "involve substantial risks of creating undesirable annoyances in international as well as domestic trade."127 The amendment might be interpreted, according to the Department of State: ${ }^{128}$

to permit a trade-mark owner to secure an injunction to prevent the distribution of literature in which certaim trade-mark words or expressions appear in a manner likely to cause the mark to lose its significance as a mark. For example, many books and dictionaries that originate abroad contain words trade-Inarked in the United States, many of which may be generic or unprotected in the foreign country.

Assistant Commissioner Leeds, on the other hand, in commenting upon the proposed amendment on behalf of the Patent Office, went on record as recognizing a need to provide a right of action against improper references to arbitrary, fanciful or coined marks in dictionaries, publications and elsewhere, but conceded at the same time that the language of the amendment was perhaps unnecessarily broad in terms since it might be held to apply even to ordinary common words used in their common siguificance. She then suggested a modified version of the proposal of S. 2540, which would accomplish the desired result without depriving the public of its right freely to use the English language. ${ }^{129}$ When the Wiley Bill was reported from the Committee on the Judiciary by Senator Wiley on August 5, 1954, ${ }^{130}$ this amendinent was deleted in its entirety and has not been restored since that time. No mention of it or of the deletion thereof appears in the Senate Report, and S. 2540 passed the Senate on August 11, 1954, without this amendment, which, consequently, was not reincorporated in the Wiley Bill when it was again introduced in both Senate and House during the present Congress. ${ }^{131}$

It remains true, then, that, at least for the foreseeable future, trademark owners can have little hope of buttressing their warning letters and pleas for cooperation with a threat of legal action under a federal antidilution law which might, at least, protect them against some instances of flagrant misuse of their trademarks. Perhaps this absence of specific statutory protection may have some superficial advantages, not only in favor of those who believe in free use of the Enghish language, or what is claimed to have become part of the English language, but also for the benefit of

127 Hearings Before the Subcommittee of the Senate Committee on the Judiciary, 83rd Cong., 2d Sess. at 52 (1954).

128 Id. at 85 (letter of the Department of State, March 24, 1954).

129 Id. at 98 (Memorandum of Daphne Leeds to The General Counsel, Department of Commerce, April 15, 1954).

130 S. REP. No. 2266, 83d Cong., 2d Sess. (1954).

131 S. 215, H.R. 7734, 84th Cong., 1st Sess. (1955). 
those trademark owners or their attorneys who may have been disinclined to go beyond the stage of letter-writing but who may then have had reason to fear that failure to follow up such letters by legal action under the proposed amendment might be construed by a court as an act of omission and, therefore, constructive abandonment on their part. In other words, they may, under the present state of the law, derive a certain feeling of comfort from the fact that they are probably powerless to go beyond the current policing practices and, therefore, cannot be held to have foregone any available avenues of trademark protection to which the proposed amendment might have opened the door.

Be that as it may, it would now seem unrealistic to expect any solution of this problem from the Congress and we will, therefore, now turn to an entirely different approach toward solution which has been adopted with notable success in many foreign countries. We refer to the trend in the decisions of the courts in almost all foreign countries not to declare a once famous trademark to have lost its significance unless no trademark ineaning whatsoever is left in the word, either in the understanding of the general public or the competitive trade. More than that, it is most interesting to note that defendants in trademark and unfair competition suits in other countries rarely succeed in persuading a court that, as a result of some misuses in publications, dictionaries, etc., a well known trademark should no longer be entitled to legal protection.

Let us briefly look at the law and decisions in some leading foreign countries, to illustrate these points.

In some countries, both in Europe and in South Anerica, any attack on a registered trademark on the ground of genericness is precluded after the issuance of the registration. In other words, in order to succeed in vitiating a trademark in those countries, it would have to be shown that the mark was in fact generic before the registration issued. The law of Argentina offers some typical illustrations of this theory. The Federal Court of Buenos Aires, in a decision involving the famous trademark, "Thermos," which was sought to be reregistered, rejected the Patent Office argument that the name had in reality become a designation of the product in commercial and domestic circles. ${ }^{132}$ Even though the word "Thermos" had been included in the fifth edition (1925) of the dictionary of the Spanish Academy, it was held that the fact that the mark may have become widely known subsequent to the registration, "could not impair the right to the exclusive use thereof as a mark, the very right which is guaranteed by the registration of such word." Since the word "Thermos" had been registered uninter-

132 Ex parte Thermos Limited de Londres, Patentes y Marcas 378 (Argentina 1940). 
ruptedly since 1907 , it was held that it had remained a registered trademark throughout and had not lost its significance. ${ }^{133}$

Similarly, in a decision involving the Spamish mark "Celofán," the Buenos Aires Federal Court reached the same conclusion as in the "Thermos" case, even though the word "Cellophane" had become publici juris in France and other countries as a result of patent expiration. ${ }^{134}$ The court there said: ${ }^{135}$

In our law, the name which was registered as a mark for a patented product, provided legal requirements are fulfilled, would indisputably be valid permanently as a mark-provided that it is re-registered im time-even subsequent to the expiration of the patent.

While other foreign countries do not put such decisive emphasis upon the fact of registration, they give almost the same measure of effective protection to the trademark owner by ruling that the public alone cannot deprive the owner of his trademark riglits but that the "distinctive quality" of a well known trademark will be upheld as long as any segnent of industry or the trade remains aware of the fact that the trademark involved designates the product of one particular manufacturer. In other words, rather than come to the unworkable solution which Judge Learned Hand reached in the famous "Aspirin" case, ${ }^{136}$ by sustaining the validity of the "Aspirin" tradeniark with regard to the medical and pharmaceutical profession but denying it with regard to the public in general, the courts in these foreign countries will, as a result of such partial retention of trademark significance, continue to protect the trademark notwithstanding the fact that, to a large extent, it may have become a "household word" in public understanding. Thus, the Supreme Court of Switzerland held in a series of cases that transformation of a trademark into a common name should not be found on the sole ground that the general public had fallen into the habit of referring to the trademark as a common noun. It would have to be shown, in addition, that even the trademark owner's own competitors and other industry members are no longer aware of the trademark significance of the term. On that ground the court sustained the famous cheese trademark "Bel Paese,"137 as well as the trademark "Lysol," 138 for

133 It may be interesting to note that the Belgian courts reached the identical conclusion with regard to the continued validity of the "Thermos" nnark.

134 Ex parte Société Anonyme La Cellopliane, Patentes y Marcas 195 (Argentina 1942). 135 Ibid.

136 Bayer \& Co. v. United Drug Co., 272 Fed. 505 (S.D.N.Y. 1921).

13760 Entscheidungen des Schweizerischen Bundesgerichts [hereinafter B.G.E.] II, 249 (1934).

13857 B.G.E. II, 609. 
a disinfectant, the trademark "Valvoline" for an oil, ${ }^{139}$ and numerous others. In the "Lysol" case, the Swiss court said: ${ }^{140}$

The transformation of a protected trademark into a free name is an extraordinary development and can be found only in most unusual cases, i.e., only where not a single person among those which come in contact with the product is aware of its protected status. If the understanding of the buying public alone would be sufficient to bring about such transformation, then the most valuable trademarks would be deprived of all protection. It is in reality the aim of the manufacturer or distributor who uses a word trademark to make his product name a household word and the more he succeeds in this undertaking, the more valuable becomes the trademark.

-..

Consequently, it was held that "Lysol," "Ichthyol," and others were still trademarks even though they were referred to generically in certain pharmaceutical and other scientific publications. The cheese trademark "Bel Paese" was sustained even though that name had appeared in conjunction with other generic cheese names in the Swiss official tariff schedule. ${ }^{141}$

Quite similar has been the development in Germany before and after World War II. It is true that the trademark "Vaseline" was thrown into the public domain in Germany as long ago as 1910, even though the German Supreme Court acknowledged its validity in the United States and other countries, ${ }^{142}$ but in the Gramophone case in $1923^{143}$ the same court refused to hold that "Gramaphone" had become part of the general language even though it had been already so adjudicated in England. ${ }^{144}$ It held that the owner's competitors were still aware of the trademark significance of the word and that it could, therefore, not be said to liave become part of the general language. ${ }^{145}$

A few weeks earlier, the German Supreme Court sustained the validity of the trademark "Sacharin."146 It there said, inter alia:"147

[S] uch a change to a trade-name can be present in the case of a registered word only when there are particular circumstances and a very clear evidence of the change of meaning of the mark is produced by the trade. Otherwise, many of the most deserving marks would be common property;

\footnotetext{
13955 B.G.E. II, 149.

14057 B.G.E. II, 606, 607. For many additional illustrations, see DAvm, KoMarrentar zUM SCHWEIZERISCHEN MARKENSCHUTZGESETZ 92 (Basel 1940).

141 von Büren, Die Entwicklung des Warenzeichens zum Warennamen (Development of a Trademark into a Trade Name), 84 ZeItSCHRIFT DEs BeRNISCHEN JURISTENVEREINS 116 (1948). 142 Decision of the German Supreme Court (Reichsgericht), IX Markenschutz und Wettbewerb (hereinafter cited as M.u.W.) 309 (1910).

143 XXIII M.u.W. 238 (1923).

144 Application of Gramophone Company, 27 R.P.C. 689 (1910).

145 XXIII M.u.W. 238.

146 XXIII M.u.W. 23 (1923).

147 Ibid.
} 
for if any one attaches to his goods continuously a mark registered for him, this will soon assume the character of a quality term with a part of the public and become the designation of a class.

Twelve years later, the famous "Roquefort" mark for cheese was sustained on identical grounds. ${ }^{148}$ In 1938 , the same court expressly stated that it was an act of unfair competition for a competitor to contribute in any way toward the development of a competitor's trademark into a common descriptive term. ${ }^{149}$

Perhaps of even greater significance is the noticeable tendency of these same courts in foreign countries not to place the exaggerated emphasis upon the appearance of a trademark in a dictionary or similar work as we are inclined to do in this country. It is perfectly legitimate and necessary, of course, for the Patent Office carefully to determine whether any word for which registration is sought has a generic meaning and to reject applications, even under section 2 (f), for registration of terms which are alleged to have become distinctive but are, in fact, part of the English language. However, entirely different and more flexible tests must be applied where a defendant in an infrimgment suit seeks to take advantage of the factusually as a matter of last resort-that the plaintiff's well known trademark may have been subject to some misuses in various publications and should therefore be held to have fallen into the public domain. In most cases of this kind the courts in foreign countries would turn a deaf ear to such contentions on the ground that inclusion in a dictionary and other misuses alone are entirely insufficient to deprive the trademark owner of its mark. If we may again refer to a German precedent, the German Supreme Court held, in a famous case, ${ }^{150}$ that inclusion of the word "Lysol" in a dictionary did not impair the trademark sigmificance of that well known mark. This was one of the very rare cases in which the trademark owner went beyond the stage of letter-writing and actually sued a publisher for infringement on the basis that the inclusion of the mark in the dictionary resulted in a dilution of the uniqueness and integrity of the mark. In that case the publisher had printed a reservation in the dictionary, advising the public that use of certain terms therein was not to be interpreted as indicating that those terms may not enjoy trademark protection. The German Supreme Court said in connection with the dictionary use: ${ }^{151}$

148 XXXV M.u.W. 220 (1935).

149 XXXVIII M.u.W. 285 (1938). For many more illustrations, see Wassermann, The Development of a Trade-Mark into a Trade-Name, translated in 24 U.S.T.M.A. BULL. 129, 157 (1929).

150 XXVII M.u.W. 12. Cited and quoted in Wassermann, Trademarks and Dictionaries, 29 U.S.T.M.A. BULI. 92, 93-94 (1934).

151 Ibid. 
The assertion that a registered trade-mark becomes a free trade-mark, or even only the assertion of the trade-mark owner, in consequence of the conduct of the defendant, that the danger exists of such transformation, is to be treated with great caution. Hence, the transformation of a registered word-mark to a trade-name cannot be recognized as in harmony with the cited jurisprudence, so long as the trade circle concerned, be it only of persons who are fannliar with the business of the disinfectant produced by the defendant and put on the market under the designation "Lysol," sees in the term an indication of a definite place of production.

If these principles, so well entrenched in the law of many foreign countries, were more widely accepted by our own courts then the passing of the proposed amendment to the act of 1946 would indeed become unnecessary, but thus far there are only a few judicial utterances which offer real encouragement in this connection and most of these are by lower courts. Thus, it was held as far back as 1934, in the "Pyramidon" case (similar to the German "Lysol" case), that the presence of a word in a dictionary should not be held conclusive proof of genericness. The court there said: ${ }^{152}$

[T] he presence of the word in the dictionary is not at all a conclusive index of its generic nature. Tradenames for popular products, as used by one inanufacturer, may become so widely known as soinetimes to be used as a synonym for the generic name itself. Striking examples of this are such names as "Kodak" and "Vaseline." Both these are defined in the dictionary and yet they are trade-marks, the use of which by any one outside the firms which have originated them would constitute an infringement. The fact that a large part of the public may associate a trade-name with the generic name for a product is a tribute to the skill with which the firm has popularized the name. To put a penalty upon such skill and to say that the generalization of the trade-name by the public as a result of the originator's publicity must deprive him of his monopoly in the name would, in the absence of special circumstances, be the height of injustice.

It may be noted in passing that the dictionary problem has occupied the attention not only of trademark lawyers but of language experts as well. ${ }^{153}$

152 H. A. Metz Laboratories, Inc. v. Blackman, 275 N.Y.Supp. 407, 414, 24 Trade-MARK Rep. 504 (1934). Cf. Derenberg, Trade-Mark Protection and Unfatr Trading 630-31 (1936). For other illustrations see Rogers, Some Suggestions to Publishers about Trade-Marks, 36 Trade-Mark ReP. 131 (1946); Rogers, Trade-Marks and Dictionaries, U.S.T.M.A. Bult. 10 (1934).

103 The problem is unusually graphically outlined in an article by Professor Vizetelly, $P$ illaging the Language, The Atlantic Monthly, Aug. 1932. Professor Vizetelly said:

"The work of making dictionaries frequently brings one face to face with problems that make things very interesting. One of these is the problem of inclusion and exclusion of trade names. Around these, political interests may revolve, as they may around the geographical names of foreign countries. So far as the trade names are concerned, there was a time when the owners of these urged dictionary makers to include them in the pages of their books.

"The experience is somewhat as follows. The proprietors advertise their goods widely; writers take the terms and introduce them in their stories or in general literature, and for ten or fifteen years all goes well. Then the owning company reorganizes, appoints new officers, engages new attorneys, and soon after this the dictionary unaker receives letters requesting the 
To revert to the more recent cases, by far the most significant would seem to be the "Polaroid" decision, ${ }^{254}$ in which one of the defences raised was that the name had lost all trademark significance. In rejecting this contention, the court said: ${ }^{155}$

On the showing made by the plaintiffs on the question of loss of distinctiveness of the trademark, one would have to be blind to deny that there has been a widespread generic use of the word "polaroid." This use has been so widespread in fact that it has found its way to the lexicographers, though most dictionary definitions quoted also recognize that the word is a trademark. It is further evident that the use of "polaroid" as a common noun has extended to stereoscopic viewers as well as to polarizing material in other applications.

As I view the cases, a defendant alleging invalidity of a trademark for genericness nuust show that to the consuming public as a whole the word has lost all its trade-mark significance. That such is the burden placed upon a defendant im cases like this one seems evident from the courts' findr ings and dicta in Du Pont Cellophane Co. v. Waxed Products Co., 2 Cir., 85 F.2d 75, and Bayer Co. v. United Drug Co., D.C. 272 F. 505. But I cannot find that the trademark "Polaroid" has come to be so public and in such universal use that nobody can be deceived by use of it. Where the possibility of some deception remains real and the need of competitors to satisfactorily describe their products is satisfied by the availability of several common nouns or adjectives suitable for that purpose, this Court will protect the interest of the owner in his trademark.

It is gratifying to realize that this was not a decision by a European or South American court, but an unusually thoughtful and forward-looking decision by a federal district court. If followed by other courts in this country, the Polaroid decision alone might accomplish almost all we had hoped to gain by the proposed amendment to section 32 of the act of 1946. It would then be realized: (a) that a well known trademark does not become a generic term unless it has lost all trademark meaning, not only within part of the general public but within the entire industry and trade, as well; (b) that occasional references to the word in dictionaries or scientific books or publications should not, in the average case, have nearly the destructive

removal of the terms froun the pages of the dictionary, as inclusion infringes the owners' rights, and protesting against such inclusion in pereunptory terms. Naturally, to one who knows the circumstances, these proceedings appear as a joke, but there is another side to them. Patented articles or products are protected for a certain period of years; but if, before the expiration of that period, the rights are sold to another company, and that coinpany does the work that the first company may or may not have neglected to do-goes to the Patent Office and registers its trademark-the new company acquires a fresh lease of hife for the name of the property that should, on the expiration of patent rights, bclong to the public.

"Men who make dictionaries do not like to omit terminology about which the public is likely to inquire, nor do they care to be threatened with vexatious lawsuits when their good faith is shown by the care that they exercise in the work they do."

154 Alvin M. Marks v. Polaroid Corp., 129 F. Supp. 243, 105 U.S.P.Q. 10 (D. Mass. 1955). 155 Id. at 270,105 U.S.P.Q. at 37 . 
significance which they have often been held to have in this country in the past; and (c) that an equity court will not encourage unscrupulous competitors to bring about the transition of a trademark into the public domain or to defend their own unfair practices by an attack on the validity of a plaintiff's trademark. Here is, at last, one recent decision in which a federal court unhesitatingly protected the distinctive quality of a famous trademark against dilution without having to resort to any federal statute or any state antidilution statute for this purpose and this even though the case arose in the state which had been the first to enact an antidilution statute.

Should it be deemed advisable or become necessary to formulate an amendment to our existing federal statute which would embody these principles in a way which would both satisfy the needs of trademark owners and protect the public in its right to free use of the English vocabulary, then much may be gained by recent experience in Great Britain and by careful study of the solution there found in the Trade Marks Act of 1938, section 15, which subsequently also became part of the Indian Trademarks Act of 1940, section 27. The Goschen Committee of 1934, after giving a great deal of thought to the problem, concluded as follows: ${ }^{156}$

\begin{abstract}
We accordingly recommend that a provision be inserted in Section 6 to the effect that the rights, whether under common law or by Statute, of the proprietor of a registered word trade mark should not be prejudiced by the fact that that word is or has become used as the name or description of an article or substance, unless it is proved that there has been and is a wellknown and established use of such word in the course of trade by some person other than the proprietor of the trade mark or a registered user, to describe in trade the particular article or substance, not being goods having any connection in the course of trade with the proprietor of the trade mark or a registered user. In the last-mentioned case, either such word should no longer be deemed to be a distinctive mark and should be removable by the Court or the Registrar from the Register on the application of any person aggrieved, or the Court or the Registrar should be empowered to give such other relief as may be suitable in the circumstances.
\end{abstract}

The Committee was motivated by the fear expressed by numerous witnesses that the employment by them of certain beneficial sales and advertising policies would, at the same time, jeopardize their trademark rights because the purchasing public might tend in practice to refer to the trademarks as the generic names of the products themselves. As a result of the Report's carefully worded recommendation, the Britislı Trade Marks Act now expressly provides that: ${ }^{157}$

156 Board of Trade, Report of the Departamental ComamtTtee on the LaW and PracTice RELATING to Trade Marks 80, $\{287$ (1934).

157 British Trade Marks Act § 15 (1938). 
[T] he registration of a trademark shall not be deemed to have become invalid, by reason only of any use, after the date of the registration, or a word or words which the trademark contains, or of which it consists, as a name or description of an article or substance.

This broad provision is then modified by certain important exceptions in case of formerly patented articles and situations in which it is proven that another competitor in the same line of business, although not associated with the trademark owner, is making "a well known and established use of the word or words as the name or description of the article or substance."168 It seems clear that the affirmative benefits conferred by this section upon trademark owners far outweigh its negative implications in certain exceptional situations; the statute makes it clear that, under British law, a trademark will be protected at least to the same extent as it was under the aboveInentioned "Polaroid"159 decision, and will not be held destroyed or impaired as a result of dictionary and similar misuses. On the contrary, it will be upheld and protected unless it can be shown that the word in fact designates a product legitimately manufactured under the same name by more than one unconnected commercial source. Legislation tending in this direction may well be suggested for our own country as overcoining some of the objections raised agamst too broad an amendment of section 32 of the Act of 1946 and at the same time providing at least some measure of statutory protection against this inost contagious form of "dilution."

IV

\section{DILUTION THROUGH IMPROPER TRADEMARK REFERENCE ON REPAIRED, REBOTTLED OR RECONDITIONED ARTICLES}

Another important area in which some specific protection under the federal statute might have been desirable involves the numerous cases in which the distinctive quality of a well known trademark is impaired or diluted as the result of unauthorized reference thereto, without the owner's consent, on rebottled, repackaged or otherwise altered products. Since the Supreme Court's decision in Prestonettes $v$. Coty, ${ }^{160}$ it had been the law that the rebottler of a famous perfume could not be absolutely enjoined from referring to the trademark as long as no other elements of unfair competition were present; in other words, it was held that the trademark was not "taboo." In its more recent decision in the Champion Spark Plug case, ${ }^{161}$ the Supreme Court largely reaffirmed the doctrine of the Coty case, but there was a dictum in Mr. Justice Douglas' opinion that the doctrine

158 British Trade Marks Act § 15, 1(a) (1938).

159 See note 152 sutpra.

160264 U.S. 359 (1923).

161 Champion Spark Plug Co. v. Sanders, 331 U.S. 125 (1947). 
should be strictly limited to situations in which the identity of the original article was still preserved. The opinion states: ${ }^{182}$

Cases may be imagined where the reconditioning or repair would be so basic that it would be a misnomer to call the article by its original name, even though the words "used" or "repaired" were added.

The Champion case did not, however, put this question to rest. The Singer Sewing Machime Company in Singer Mfg. Co. v. American Appliance Co. ${ }^{103}$ secured drastic but not complete relief against a defendant who had rebuilt old "Singer" machines, and got an even more sweeping injunction in a subsequent case in California, in which the court observed that "a rebuilder's notice on the machines is not a license to use plaintiff's trademark." 184 In the latter case, any nention of the word "Singer" was enjoined except a carefully worded reference to the fact that a used "Singer" head was used as part of the machine. ${ }^{165}$

In Green v. Electric Vacuum Cleaner Co., ${ }^{166}$ the court's decree enjoined the defendant "from offering for sale or selling reconditioned or reconstructed vacuuin cleaners using plaintiff's trademarks Premier or Premier Duplex, or either of them, in the manner which has been einployed; but not if the reconditioned or reconstructed vacuum cleaners are marked as prominently as the trademarks, to indicate that the reconditioning or reconstruction was done by the appellant." ${ }^{167}$ Another plaintiff inore recently succeeded in securing a court order compelling a rebuilder to remove the name "Electrolux" froin its "rebuilt" cleaners. ${ }^{168}$ The court there said: ${ }^{169}$

It is no answer to say that the cleaner will function even with parts or equipment made by other manufacturers. Plaintiff is not to be subjected to the possibility of mefficient functioning by reason of the use of parts or equipment made by others. Unless the entire cleaner as it reaches the user is wholly and completely the product of plaintiff, plaintiff's name may not be used in connection with the cleaner or the sale thereof.

All these cases, to a lesser or greater extent, seem to reflect Judge Learned Hand's nuch quoted observation in the Yale case that, "... a reputation like a face is the symbol of its possessor and creator, and another can use it only as a mask ..., m70 and his further comment that a

182 Id. at 129.

16386 F. Supp. 737 (N.D. Ohio 1949).

104 Singer Mfg. Co. v. Redlich, 109 F. Supp. 623, 625 (S.D. Cal. 1952).

165 The most recent Singer case is Singer Mfg. Co. v. Singer Upholstering \& Sewing Co., 130 F. Supp. 205 (W.D. Penn. 1955).

168132 F.2d 312 (6th Cir. 1942).

187 Id. at 315 .

168 Electrolux Corp. v. Michaels Bros., 207 Misc. 60, 137 N.Y.2d 92 (1954).

109 Id. at 63-64, 137 N.Y.2d at 95-96.

170 Yale Electric Corp. v. Robertson, 26 F.2d 972, 974 (2d Cir. 1928). 
complaining party need not "permit another to attach to his goodwill the consequences of trade methods not his own, and need not expose his good name to the hazards of another's conduct."171

It was, therefore, but a further step in this direction when the earlier versions of the Lanham Act, until shortly before its enactment, included the following provision: ${ }^{172}$

If goods bearing a registered mark have been put on the market by or with the authority of the registrant of a registered mark, or in any package or other contamer bearing said mark, and a notice that the goods may be resold only unaltered or unrenovated or in the origmal package or container, and said goods or any part thereof have, without the authority of the registrant, been transferred to another package or container or been in any way altered or renovated, any person who shall, in commerce, make any use of or refer to said registered mark upon or in connection with the sale or advertising of such transferred or altered or renovated goods, shall be hable to a civil action by the registrant for any or all of the remedies hereinafter provided.

Strong opposition by the representatives of the Antitrust Division of the Department of Justice during the hearings on H.R. 82 was raised against this proposal: ${ }^{173}$

In connection with used or second-hand products this section would in many industries give the manufacturer a right of veto on every sale of machines or products in a renovated or repaired condition if the original trade-mark were still affixed or if the trade-mark name were necessary to identify a product or a part which was being sold. This is an unprecedented grant of power to control a chattel after its sale and throughout its existence. Such power would tend to further concentrate control over distribution in the hands of large manufacturers and in many industries might place existing independent dealers in used and renovated products in the same position and subject to the same controls as sales agencies of the manufacturer.

The provision was eventually eliminated from the statute, so that our present federal trademark act includes neither criminal nor civil provisions specifically directed against unauthorized or misleading use of trademarks on reconditioned, rebottled, repackaged, or otherwise altered articles. While liberal court decisions have provided trademark owners with some relief in cases of palpable fraud, it is still believed in many quarters that more specific and effective federal protection should be available in cases of this sort (as is true in the majority of foreign countries).

We may well inquire, therefore, to what extent existing state statutes

171 Yale Electric Corp. v. Robertson, 26 F.2d 972, 974 (2d Cir. 1928).

172 H.R. 82, 78th Cong., 2d Sess. § 32(3) (1944).

173 DePARTMENT OF JUSTICE, REPORT ON H.R. 82 at 63 (1944); Hearings Before the Subcommittee of the Senate Committee on Patents, 78th Cong., 2d Sess. at 71, 141 (1944). 
and, more particularly, the antidilution statutes may be resorted to to fill this gap. In this respect, attention is immediately focused on the fact that quite apart from the antidilution statute, almost all the states have so-called "refillable container" statutes and other criminal provisions which make the use of trademarked bottles, containers and the like a misdemeanor; these state statutes may, therefore, be used in a variety of cases in which our federal law has remained ineffective, if not, indeed, nonexistent. That, quite apart from these criminal provisions, the broad language of the antidilution statutes may also be rehed upon by the trademark owner, may be gathered from at least one recent case which arose in the federal court in New York and in which the New York Antidilution Statute was expressly relied upon as at least one important basis for protection. This was the case of Wertheimer v. Milliken, ${ }^{174}$ in which the defendant had purchased certain dental X-ray film bearing plaintiff's trademark, the containers of which were marked "Not Fit for Use," and which were to be offered by defendants to the public only as scrap. Defendants, however, obscured the words "Not Fit for Use" so that the film was not sold as scrap but in such a manner as to injure the good name and reputation of plaintiff and its trademark. In granting rehef, the federal court rehed expressly on the New York Antidilution Statute, saying: ${ }^{\mathbf{7 7 5}}$

The riglit to injunctive relief under such circumstances is clear, in view of the recent amendment to the New York General Business Law, McK. Consol. Laws, c. 20, which became effective July 1, 1954.

A temporary injunction was granted and the conduct of defendant was lield to constitute unfair competition under the Antidilution Statute.

It is interesting to compare this recent case with the decision of the Court of Appeals for the Seventh Circuit in Stahly, Inc. v. M. H. Jacobs Co., ${ }^{176}$ which was decided before the Illmois Antidilution Statute was enacted. The defendant there was enjoined from selling plaintiff's razor blades without indicating to the public that they were defective, but relief was granted solely on the basis of protection of the public against fraud and it was not suggested that the sale of plaintiff's trademarked product in such a manner miglit, without more, constituted trademark infringement or dilution, as that term was defined in the subsequently adopted Illinois Antidilution Statute.

It may thus be confidently expected that the coverage of the state antidilution statutes will be held broad enough to give relief even in some situa-

\footnotetext{
174123 F. Supp. 358 (S.D.N.Y. 1954); see also note 93 supra.

175123 F. Supp. at 360.

170183 F.2d 914 (7th Cir. 1950).
} 
tions in which a federal court might hesitate to do so under the more restricted language of the Coty and Champion Spark Plug cases. ${ }^{177}$

The same is perhaps even more true in cases not involving reconditioned or otherwise changed products but unnecessary and unfair references to the trademark owner's product for the purpose of gaining a competitive advantage. Typical illustrations of this sort occur where the trademark is referred to in such form as "a substitute for............." or "X-type............." or "equivalent of............." or "as good as............." etc. Under the laws of most foreign countries such references, unless excusable as a matter of commercial necessity, would fall within the category of trademark infringement; they might readily fall within the broad scope of the language of the antidilution statutes in our country. It is true that even in the absence of statutory provision to this effect, some progressive courts have enjoined such uses as unfair competition; for instance, the New York State Court in Winthrop Chemical Co. v. Blackman. ${ }^{178} \mathrm{~A}$ majority of the court held that the practice of using the words "introduced as" or "equivalent of" in conjunction with the plaintiff's trademark name was "designed to foist the defendant's product on the buyer without any necessity of so doing in the interest of the public to prevent monopoly."179 It would undoubtedly add to the security of trademark owners if some statutory basis either in the federal law or in the state antidilution statute were available on which to prosecute practices of this sort.

Here, again, a casual glance at the present British law may not be amiss. After the House of Lords had held in the famous Yeast-Vite case $\mathrm{e}^{180}$ that a collateral reference to a trademark in the form of "a substitute for" did not constitute trademark infringement, the Goschen Committee recommended that the statute be changed so as to make any such reference without the proprietor's consent an infringement of the trademark, even if such use may not be likely to lead to the belief that there was a connection in the course of trade between the goods involved. ${ }^{181}$ In accordance with this recommendation, the Trade Marks Act of 1938 expressly defines trademark infringement so as to include this type of collateral use and the new section was successfully invoked by the plaintiff in the subsequent case of Bismag Ltd. v. Amblins (Chemists) Ltd., ${ }^{182}$ although the language and scope of the amendment was criticized by the British court. ${ }^{183}$

\footnotetext{
177 See notes 160 and 161 supra.

178246 App. Div. 234, 285 N.Y. Supp. 443 (Sup. Ct. 1936).

179 Id. at 235,285 N.Y. Supp. at 444.

180 Irving's Yeast-Vite Ltd. v. Horsenail, 51 R.P.C. 110 (1934).

181 BOARD OF TRADE REPORT, note 156 supra at $\$ 185$, p. 50.

18257 R.P.C. 209 (1940).

183 Ibid. Interestingly enough, as a result of such criticism the recent REPORT OF THE Conouttree Appointed by the AtTorney-Generat of THE Comaronweatth (of Australia) to consider alterations in the Australian Trade Marks Law, note 90 supra, did not recommend an amendment to the Australian Act in this respect.
} 
The New Canadian Trade Marks Act of 1953 has generally followed the lead of the English statute but has much improved the wording of the British law by providing as follows: ${ }^{184}$

22. (1) No person shall use a trade mark registered by another person in a manner likely to have the effect of depreciating the value of the goodwill attaching thereto.

This, of course, in one short sentence incorporates the philosophy of our antidilution statutes into the new Canadian Trade Marks Act since this language is broad enough to cover not only the situations under discussion but all those previously referred to as well. In recommending this salutary legislative provision, the Report of the Canadian Trade Mark Law Revision Committee stated: ${ }^{185}$

We have been impressed by the fact that infringement actions have sometimes been decided on wholly artificial rules, as the Yeast-Vite case above noted indicates. A trade mark statute should be designed to protect fair trading and, in our view, anything that depreciates the value of the goodwill attaching to a trade mark should be prohibited. We have, therefore, made a positive provision to that effect in Section 22 . If, therefore, a well known trade mark is used by other than the trade mark owner in such a manner as would not previously have constituted grounds for an action either of infringement or passing off, but which has the effect of bringing the trade mark into contempt or disrepute in the public mind, the trade mark owner will be in a position to seek a remedy.

The Report expressed the hope that with this broad provision as part of the trademark statute, "unfair competition will be minimized and ... the honest and healthy use of trade marks will be encouraged."188 The inclusion of a similar provision in our Federal Trademark Act would signify the acceptance of the philosophy of the State Antidilution Statutes. ${ }^{187}$

$\mathrm{V}$

"INJURY TO BUSINESS REPUTATION"

Little attention has been given thus far by our courts or by writers in the field to the fact that the four antidilution statutes which have thus far

\footnotetext{
184 An Act relating to Trade Marks and Unfair Competition, 1 \& 2 Eutz. 2, c. 49 (Canada 1953).

185 Canadian Trade Mark Law Revision Comantiee, Report 26-27 (1953).

180 Ibid.

187 See note 7 supra. It is perhaps interesting that this form of dilution by use of trademarks on repair parts and altered goods has also been suggested as a topic for international regulation. The International Association for the Protection of Industrial Property has long favored the inclusion of a provision in the Convention making unauthorized use of trademarks on repair parts an act of trademark infringement. However, neither the International Chamber of Commerce nor the International Law Association are in favor of the proposal, but rather have expressed the opinion that each country should deal with this particular problem in its own domestic legislation.
} 
been enacted all refer not only to "dilution of the distinctive quality of a trade name or trademark" but, in the first place, to "likelihood of injury to business reputation." 188 While the history of these statutes, particularly the Massachusetts statute, seems to indicate that they are directed primarily toward protecting the trademark owner against use of his trademark on totally unrelated products, the language of the acts apparently covers a far greater range by making actionable "injury to business reputation," in addition to or independent of any other element of dilution. It is significant, in this connection, that the statutes use the disjunctive "or" in distinguishing between these two types of injury. Thus far there has been no decided case in any of the four states in which other previously unrecognized forms of injury to business reputation have been successfully enjoined under the antidilution statutes. It would certainly not seem farfetched, however, to suggest that in states such as New York, certain other forms of injury to business reputation may now have become actionable for which no equitable remedy was held to exist prior to the enactment of the antidilution statute. It may not be too optimistic to prophesy that the form of injury to business reputation which we have always referred to under the misnomer of "trade libel" may soon be effectively restrained even in New York as a form of unfair competition under this recent statute, even though neither the New York Court of Appeals ${ }^{189}$ nor the Court of Appeals for the Second Circuit ${ }^{190}$ has thus far deviated from the outmoded and unfair doctrine of the old Marlin Firearms decision. ${ }^{101}$ In this way, that part of the New York State Antidilution Statute which refers generally to "injury to business reputation" may pave the way not only to more effective trademark protection but to the gradual recognition of other actionable forms of unfair business conduct as well. ${ }^{102}$

VI

THE "DILUTION" PROBLEM UNDER THE INTERNATIONAL AND INTER-AMERICAN CONVENTIONS

The problem of protecting well known trademarks against dilution has, of course, arisen not only on the domestic level but in the realm of international trademark protection as well. While the International Convention

188 See statutes cited at note 7 supra.

180 Advance Music Corp. v. American Tobacco Co., 296 N.Y. 79, 70 N.E.2d 401 (1945). Although applying a more liberal rule with regard to the requirement of "special damages" in trade libel cases, the court of appeals made no mention of the Marlin Firearms case, note 191 infra, and gave no indication that it meant to overrule that decision.

190 Eversharp, Inc. v. Pal Blade Co., 182 F.2d 779 (2d Cir. 1950).

101 Marlin Firearms Co. v. Shields, 171 N.Y. 384, 64 N.E. 163 (1902).

${ }^{102} C f$., with regard to this problem generally, Note, The Law of Commercial Disparagement: Business Defamation's Impotent Ally, 63 YaLE L.J. 65 (1953). 
for the Protection of Industrial Property ${ }^{193}$ in its original version did not include any stipulation for the protection of well known trademarks, the now famous article 6bis was incorporated in The Hague Revision of 1925, which, in its first two paragraphs, provides as follows:

1. The countries of the Union agree to refuse or invalidate either administratively, if their legislation so permits, or at the request of an interested party, the registration of a trade-mark which constitutes a reproduction, imitation or translation, liable to create confusion with a mark considered by the competent authority of the country of registration to be well known there as being already a nnark of a person entitled to the benefits of the present Convention and used for identical or similar products. The same action shall be taken when the essential part of the mark constitutes a reproduction of a well-known mark or an imitation likely to cause confusion therewith.

2. A period of at least three years must be granted in order to claim the cancellation of these marks. The period shall start from the date of registration of the inark.

This Convention article introduced the concept of the "notoriously well known trademark" into the law and it would seem at first glance as if the concept of dilution thus found its way into the international sphere of trademark protection and unfair competition even before the problem itself was first recognized in our own domestic law. Upon closer scrutiny, however, it becomes apparent that article 6bis in its present form is a far cry from establishing an effective international system of protection for world-famous trademarks, but is strictly limited to grant protection to the first user of a trademark in one Convention country against a person who may have succeeded in getting a registration for the same mark in another member country before the first user had secured a registration there. In such a situation-and only in that case - the first user is given a three-year period within which he may seek cancellation of such registration by a third party. In other words, it was the primary purpose of article 6bis to remove the inequities which flow from first registration of well known trademarks by pirates in countries in which trademark ownership is acquired by registration rather than by first use. The courts of most countries have held that, for the purpose of taking advantage of article 6bis, it must be shown that the mark is well known not only in the country of origin but likewise in the country where protection is sought against the prior registrant.

While article 6bis, in this limited scope, was an important step forward at the time of its adoption, it has since been clearly recognized that it is

193 Convention of Union of Paris for the Protection of Industrial Property, March 20, 1883; revised at Brussels, Dec. 14, 1900; at Washington, June 2, 1911; at The Hague, Nov. 6, 1925; and at London, June 2, 1934. 
still far too restricted and that it should be amended at the forthcoming Diplomatic Conference at Lisbon in at least three vital respects, one of which has direct reference to the subject of "dilution." As a result of extensive studies not only by various international groups, such as the International Association for the Protection of Industrial Property, the International Chamber of Commerce, the International Law Association, and others, ${ }^{194}$ but also by distinguished writers and scholars, ${ }^{105}$ both here and abroad, the following recommendations may be offered.

$A$. All writers and international study groups are agreed that the 3-year cancellation period presently included in article 6 bis is too short and should be extended to at least five years.

$B$. The owner of a well known trademark should be protected in other Convention countries in advance of actual use in such countries, provided the mark has become known there. In other words, actual use of the mark on goods imported into other Convention countries should not be required and use by way of advertising or other means of publicity should be held sufficient. This could be accomplished if a provision were added to article 6bis which would read as follows: ${ }^{196}$

A mark should be deemed "well known" for the purposes of this article if such mark has been used in the country involved or has been made known to the trade or the general public by local or foreign advertising, or by other means of publicity.

194 The International Chamber of Commerce was particularly active; cf. Memorandum prepared by Dr. Stephen P. Ladas, Chairman, and Mr. Charles Magnin, Rapporteur, of the International Chamber of Commerce Commission on International Protection of Industrial Property, entitled "Well-Known Trade Marks," presented at Lisbon, June 1951, at the 13th Congress of the I.C.C., published in Enghish in booklet form by the Commission, C.C.I. Brochure 138, also published by the Trade Marks Patents and Designs Federation as a supplement to its monthly report (London, May 1951). Cf. also, International Law Associntron REPORT OF THE FORTY-FIFTH CONFERENCE, LUCERNE, 1952, 201 et seq. (London, 1953); INTERNational LAW Association, Report of tHe ForTy-Fourth CoNfERENCE, CopenhaGen, 1950, 86 (London, 1952).

${ }^{195}$ Cf. in English, Callmann, Thoughts on the Protection of World Marks, 44 Trade-MarK REP. 1134 (1954); Ladas, International Protection of Well-Known Trade-Marks, 41 TRADEMARK ReP. 661 (1951) ; in French, Fernand-Jacq, Refiexions sur les Marques Dites "Notoires," 68 La Propríté INdustrielese 189 (1952); Martin-Achard, La Protection des Marques Notoirement Connues, 46 Scaweizerische Jurtsten Zetrung 117 (1950); in German, Remmer, WETTBEWERBS UND WARENZETCHENRECHT (Commentary to the Law of Unfair Competition and Trade-Marks), 48 et seq. (3d ed. 1954); Becher, Der Schutz der berïhmten Marke, 53 GeWERBLTCHER RECHTSSCHUTZ UND URHEBERRECHT 489 (1951); Moser von Filseck und Schreiber, Der Schutz Notorisch Bekannter Marken, Austands UND INTERNATIONALER TEIl zU GRUR 70 (1952); Troller, Die Berühmte Marke, FESTGABE DES LUZERNISCHEN ANWALTSVETBandes zUM SCHWEIzERIschen ANwatistag (1953). For the latest discussion of the need for amending Article $6 \mathrm{bis}$ of the International Convention, see Bodenhausen, 46 Trademark REP. 718 (1956).

196 International Law Association, American Branch, Report for the meeting at Lucerne, Aug. 31-Sept. 6, 1952, printed in Report of the 45th Conference, note 194 sulpra, at p. 203. 
This recommendation was made and adopted at the Lucerne Meeting of the International Law Association and had been previously recommended in identical form in the Ladas-Magnin Report to the International Chamber of Commerce. ${ }^{197}$ It will be noted that this proposal goes beyond artiticles 7 and 8 of the Inter-American Convention of Washington, 1929, 198 which authorized the owner of a mark to apply for cancellation of marks registered in another Convention country which had been previously used by the petitioner, provided the registrant of the mark sought to be cancelled or opposed had actual knowledge of the prior use or registration of the petitioner's mark in his home country. As pointed out by Dr. Ladas, ${ }^{199}$ it would be difficult to prove the subjective element of actual knowledge, and it would be far better, therefore, to write into the Convention the concept of "made known" as first used in the Canadian Unfair Competition Act of $1932^{200}$ and as re-embodied in the Canadian Trade Marks Act of $1953{ }^{201}$ Section 5 of the latter act expressly provides that a trademark will be deemed to have been made known in Canada, inter alia, if the goods or services to which the mark relates have been advertised in any printed publication circulated in Canada "in the ordinary course of cominerce among potential dealers in or users of such wares or services" or have been similarly advertised in radio broadcasts "ordinarily received in Canada by potential dealers in or users of such wares or services." Any trademark that "has become well known in Canada by reason of such distribution or advertising" shall be deemed to be in use there and to be entitled to Convention protection.

It would indeed be a considerable step forward if international protection of trademarks owned by persons entitled to Convention protection would become available not only as a result of use and registration in Member Countries, but also on the basis that they have been "made known" in such countries as the result of advertising, broadcasting and similar means of publicity.

$C$. Thus far, the proposals referred to affect only the extraterritorial protection of trademarks without going beyond the normal substantive scope of the mark itself and without even beginning to approach the dilution problem. On the contrary, article 6bis limits the protection of notoriously well known marks expressly to use of the mark by others on identical or similar products. No provision is made in any existing international convention for protection of any mark, no matter how famous, against use on

197 Note 194 supra.

198 Robert, THE NEw TRADE-Mark MandaI 313 (1947) in which is printed the General Inter-American Trade-Mark Convention, February 20, 1929.

19941 TRADE-MARK REP. 661, 663 (1951).

200 22-23 GEORGE 5, c. 38 (Canada 1932).

201 Note 184 supra. 
completely unrelated or dissimilar products. In other words, neither article 6 bis nor any other Convention provision (unless, conceivably, the rather broad provision of article 10bis, may be resorted to for this purpose) may be invoked by owners of famous trademarks, such as "Lucky Strike," "Kodak," "Leica," Chanel," "Omega," or innumerable others, to prevent dilution of these names as the result of use on totally unrelated products. This is the reason why it has been repeatedly pointed out by well known foreign scholars ${ }^{202}$ that the concept of notoriously well known trademarks, as defined in article $6 \mathrm{bis}$, should be strictly distinguished from that of a "celebrated" or "famous" trademark, because such celebrated trademarks have been held entitled, in many foreign countries, to protection far beyond the limited scope of so-called "notoriously well known" marks under article 6 bis. This is the reason, too, why proposals have been made in the past $^{203}$ and are still being suggested ${ }^{204}$ for the creation of the concept of a "world trademark" entitled to worldwide protection not limited to the same or similar goods for which the mark has become famous.

In order to meet this challenge, the International Chamber of Commerce suggested an amendment to article $6 \mathrm{bis}$, which read as follows: ${ }^{205}$

The stipulation of the first paragraph of this Article shall also be applied in the case where the mark attacked by the interested party is used on dissimilar products provided, however, the competent authorities shall consider that the mark, by reason of its uniqueness or originality or its long and exclusive use by the interested party or its exceptional advertising, if used by the other person may lead the public to believe that such dissimilar products originate with the interested party or their standards are guaranteed by him or are made by a person in relation to him. ${ }^{206}$

It should be noted that even this proposal, which goes far beyond the present scope of article 6bis, does not go as far as to create a cause of action on the ground of "dilution" of a famous name in the absence of any possibility of confusion, even in the broadest sense of that term, but would

202 Becher, Troller, supra note 195.

203 The first such proposal was made by the late Edwin Katz in a book entitled WertMARKENRECHT (Berhin 1926).

${ }^{204}$ Callmann, Thoughts on the Protection of World Marks, 44 TRADE-MARK REP. 1134 (1954).

205 Ladas-Magnin Report, supra note 194.

208 The International Law Association at the Lucerne meeting reformulated this proposal in the following language, which, it is suggested, is preferable to that adopted by the International Chamber of Commerce: "The first paragraph of this article shall also be applicable in cases in which a well-known mark has been registered in another Convention country for dissimilar goods, provided a proper showing can be made that the mark, as a result of its uniqueness and celebrity, has become so well-known as to induce members of the trade or the general public to assume that there may be a connection in trade between the user or registrant of the mark on dissimilar products and the owner of the well-known mark." (Report of the 45tll Conference, supra note 194, at 204.) 
still be restricted to situations in which the simultaneous use of the name or mark by more than one party on totally different goods might give rise to the erroneous behef that some connection in trade may exist between the parties involved. It has been suggested that even this limitation should not be necessary and that actually celebrated trademarks or names, such as, for instance, "Mickey Mouse," should be entitled to Convention protection merely on the ground that their use by others than their well-known owners forms an act of piracy or misappropriation or unjust enrichment, whichever of these terms may seem best to characterize such unfair conduct.

We are all aware, of course, of the great difficulty which would have to be faced in trying to define the meaning of famous or celebrated trademarks, as distinguished from notoriously well known marks presently encompassed within article 6 bis of the Convention. Dr. Troller's and Dr. Becher's studies ${ }^{207}$ may go a considerable way toward suggesting a solution to this problem. ${ }^{208}$ Becher states in this respect: ${ }^{209}$

"Celebrated" means known to the people of a sovereign territory irrespective of class of purchasers, of friend or foe, of differences of class or education, of age or youth. A mark is celebrated when it has entered into the language of a people with a definite and therefore single signification.

He also points out ${ }^{210}$ that ordinarily a mark might not be "celebrated" unless a court took judicial notice of its fame: $:^{211}$

For a mark that is not familiar and does not convey an exact meaning as a household word to even one judge is certainly not celebrated. If the court has to ask for proof that the mark is celebrated, especially in the form of letters from abroad (!), I regard this as confirmation that it is not a mark celebrated outside its own class of goods.

$D$. Fimally, it has been proposed that rather than amend article 6 bis along the lines previously referred to, one broad amendment to article 10bis of the Convention might satisfy the need for more effective protection of famous trademarks. Such a proposal was made before the Quebec Congress of the International Chamber of Commerce and led to a resolution recommending the inclusion of the following provision in article 10bis: ${ }^{212}$

207 Becher, Troller, supra note 195.

${ }^{208}$ An excellent English translation of the Becher article was prepared by L.A. Ellwood, for the Trade Marks Patents and Designis Federation and published as Part I of its Report for March 1952.

209 Id. at 2.

$210 I d$. at 3.

211 Cf. Heydt, Zum Begriff der Weltmarke (World Trade-Mark), 54 GewerbircHER REICETSSCHUTZ UND URHEBERRECHT 321 (1952).

21212 th Congress (Summer 1949). 
The use or registration by a person of a mark which by reason of its originality and uniqueness or of its long and exclusive use by another has come to symbolize and identify his entire busmess or commercial activity shall be deemed to be an act of unfair competition.

This provision was also adopted at the Copenhagen Conference of the International Law Association. ${ }^{213}$ It would seem, however, that if the protection of famous trademarks against dilution were made an act of trademark infringement by way of appropriate amendments to article 6bis, rather than by including it merely in a general program of international protection against unfair competition, a more specific and more readily enforceable mode of protection would become available.

Whichever of these proposals may meet with the approval of the forthcoming Diplomatic Conference on the revision of the International Convention at Lisbon, it cannot be doubted that the ultimate adoption of any one of these proposals would constitute a welcome and necessary strengthening of the protection of famous trademarks against dilution in the channels of international trade. 